\title{
Persistent Pain Maintains Morphine-Seeking Behavior after Morphine Withdrawal through Reduced MeCP2 Repression of Glua1 in Rat Central Amygdala
}

\author{
Yuan-Yuan Hou, You-Qing Cai, and Zhizhong Z. Pan \\ Department of Anesthesiology and Pain Medicine, The University of Texas MD Anderson Cancer Center, Houston, Texas 77030
}

\begin{abstract}
As long-term opioids are increasingly used for control of chronic pain, how pain affects the rewarding effect of opioids and hence risk of prescription opioid misuse and abuse remains a healthcare concern and a challenging issue in current pain management. In this study, using a rat model of morphine self-administration, we investigated the molecular mechanisms underlying the impact of pain on operant behavior of morphine intake and morphine seeking before and after morphine withdrawal. We found that rats with persistent pain consumed a similar amount of daily morphine to that in control rats without pain, but maintained their level-pressing behavior of morphine seeking after abstinence of morphine at $0.2 \mathrm{mg} / \mathrm{kg}$, whereas this behavior was gradually diminished in control rats. In the central nucleus of amygdala (CeA), a limbic structure critically involved in the affective dimension of pain, proteins of GluA1 subunits of glutamate AMPA receptors were upregulated during morphine withdrawal, and viral knockdown of CeA GluA1 eliminated the morphineseeking behavior in withdrawn rats of the pain group. Chromatin immunoprecipitation analysis revealed that the methyl CpG-binding protein $2(\mathrm{MeCP} 2)$ was enriched in the promoter region of Grial encoding GluAl and this enrichment was significantly attenuated in withdrawn rats of the pain group. Furthermore, viral overexpression of CeA MeCP2 repressed the GluA1 level and eliminated the maintenance of morphine-seeking behavior after morphine withdrawal. These results suggest direct MeCp2 repression of GluA1 function as a likely mechanism for morphine-seeking behavior maintained by long-lasting affective pain after morphine withdrawal.
\end{abstract}

Key words: addiction; AMPA receptor; epigenetic; opioid withdrawal; pain; transcription repression

\section{Introduction}

Chronic pain is a neurological disease that alters physical sensation of pain (sensory pain) and also induces comorbid, emotionally distressful disorders (affective pain), which further exacerbates and perpetuates sensory pain (Bushnell et al., 2013). Currently, opioids remain the most effective analgesics; however, repeated opioid use in healthy individuals causes opioid dependence and addiction, characterized by an intensive urge or craving of compulsive opioid use to avoid devastating withdrawal symptoms (Li et al., 2008; Theberge et al., 2012). Prescription of long-term opioids for chronic pain in patients has long been a concern of causing misuse and abuse although the rate of these incidences is unclear and controversial (Ballantyne and LaForge, 2007; Denisco et al., 2008; Passik and Kirsh, 2011; Hunt and Urch, 2013). Nonetheless, preclinical and clinical studies on opioid use and abuse in the context of chronic pain remain limited. Available clinical reports on opioid use and abuse in pain patients

\footnotetext{
Received Aug. 18, 2014; revised Jan. 16, 2015; accepted Jan. 22, 2015.

Author contributions: Y.-Y.H., Y.-Q.C., and Z.Z.P. designed research; Y.-Y.H. and Y.-Q.C. performed research;

Y.-Y.H., Y.-Q.C., and Z.Z.P. analyzed data; Y.-Y.H. and Z.Z.P. wrote the paper.

This work was supported by NIH National Institute on Drug Abuse Grants DA023069 and DA027541.

The authors declare no competing financial interests.

Correspondence should be addressed to Dr Zhizhong Z. Pan, Department of Anesthesiology and Pain Medicine,

The University of Texas MD Anderson Cancer Center, 1515 Holcombe Boulevard, Unit 110, Houston, TX 77030.

E-mail:zzpan@mdanderson.org.

DOI:10.1523/JNEUROSCI.3453-14.2015

Copyright $\odot 2015$ the authors $\quad 0270-6474 / 15 / 353689-12 \$ 15.00 / 0$
}

under opioid therapies are still ambiguous and inconsistent due to the lack of suitable approach and adequate research (Minozzi et al., 2013).

The amygdala complex, particularly the central nucleus of the amygdala (CeA), is a key limbic structure that mediates and integrates emotional responses to both positive, motivational stimuli, such as drug reward, and negative, aversive stimuli, such as fear and pain (Johansen et al., 2001; Leknes and Tracey, 2008; Baliki et al., 2010). Recent research has demonstrated a crucial role of CeA in associative learning and emotional integration of both opioid reward and pain experience through extensive reciprocal connections with forebrain reward circuitry and brainstem pain-processing networks (Fields, 2004; Lu et al., 2005; Neugebauer et al., 2009; Bie et al., 2012; Cai et al., 2013). Thus, CeA may serve as an important hinging brain site to understand the functional interactions between aversive effect of affective pain and euphoric effect of opioid reward that drives opioid abuse and addiction.

The glutamate AMPA receptor (AMPAR), assembled mainly by GluA1 and GluA2 subunits (Wenthold et al., 1996; Isaac et al., 2007), plays an essential role in central synaptic plasticity involved in many brain functions and neurological diseases. Formation of GluA2-lacking, homomeric GluA1 AMPARs with high $\mathrm{Ca}^{2+}$ permeability leads to synaptic strengthening required for long-term synaptic plasticity and associative learning and memory (Mahanty and Sah, 1998; Hayashi et al., 2000; Rumpel et al., 
2005; Bowers et al., 2010). GluA1 upregulation profoundly promotes motivational response to drugs of abuse (Carlezon et al., 1997; Conrad et al., 2008; Choi et al., 2011; Cai et al., 2013). Pain conditions also upregulate GluA1 in central neurons with potentiated nociceptive transmission (Guan et al., 2003; Larsson and Broman, 2008; Xu et al., 2008).

Therefore, in this study, we investigated the role of CeA GluA1 in the pain effect on behaviors of opioid intake and opioid seeking in a rat model of morphine self-administration (MSA), and determined how GluA1 was transcriptionally regulated under the behavioral conditions.

\section{Materials and Methods}

Animals. Male Wistar rats weighting 250-300 g were used in this study. Rats were housed two to three per cage and maintained on a $12 \mathrm{~h}$ light/ dark cycle with access to food and water ad libitum unless otherwise specified. All procedures involving the use of animals conformed to the guidelines by the Institutional Animal Care and Use Committee of MD Anderson Cancer Center.

Pain model and pain test. Complete Freund's adjuvant (CFA; $50 \mu \mathrm{l}$, Sigma-Aldrich) or saline was injected into the plantar of left hindpaw under isoflurane (3\%) anesthesia. Paw withdrawal latency to a noxious thermal stimulus was recorded to determine CFA-induced hyperalgesic behavior of sensory pain with a Hargreaves analgesic instrument (Stoelting).

$C P A$. Conditioned place aversion (CPA) paradigm has been widely used to measure affective dimension of pain (Johansen et al., 2001; Hummel et al., 2008). The place conditioning apparatus (MED Associates) was the same as that we used in our previous studies of conditioned place preference (Bie et al., 2012; Cai et al., 2013; Zhang et al., 2014b). It has three compartments: one neutral compartment and two conditioning compartments with distinctive visual and tactile cues and removable doors. The CPA procedure consisted of three phases: pretest, place conditioning and post-test. In pretest, a rat was placed in the neutral compartment and allowed to explore all compartments freely for $20 \mathrm{~min}$. The time spent in each compartment was recorded. Rats that spent $>60 \%$ of the time in one compartment were excluded from the experiment. For place conditioning, rats were injected with saline after the pretest and $1 \mathrm{~d}$ after saline injection, the rat was confined in one of the conditioning compartments for $45 \mathrm{~min}$. Four to $5 \mathrm{~h}$ later on the same day, the rat received an intraplantar injection of CFA (pain group) or saline (control group). One day after CFA injection, the rat was confined in the other compartment for $45 \mathrm{~min}$. Thus, rats were paired with the respective compartment for place conditioning $1 \mathrm{~d}$ after injection of saline or CFA. Post-test (similar to the pretest) was performed in both pain and control groups of conditioned rats, starting $3 \mathrm{~d}$ after CFA injection and continuing once every other day for $31 \mathrm{~d}$. CPA scores were defined by the difference of time spent in CFA-paired compartment between pretests and post-tests.

Food reward. The operant chamber (MED Associates) has two levers: one paired with reinforcement delivery (active lever) and the other with no programmed consequence (inactive lever). To accelerate acquisition and establishment of lever-pressing behavior for MSA, food was restricted to $15 \mathrm{~g} / \mathrm{d}$ and rats were trained to press the lever on a reinforcement schedule of fixed ratio 1 (FR1) during a 30 min session daily. Pressing the active lever resulted in the delivery of a food pellet ( 45 $\mathrm{mg}$ ) with or without illumination of a cue light above the lever, followed by a $5 \mathrm{~s}$ timeout period. Daily lever-pressing sessions continued until the rat self-administered 100 pellets per session for three consecutive sessions. Then, the rats were freely fed for $1 \mathrm{~d}$ before CeA infusions of viral vectors. Food was provided ad libitum in all other behavioral sessions.

Adeno-associated virus vectors and CeA microinjection. Open reading frame sequence of rat methyl $\mathrm{CpG}$ binding protein 2 (MeCP2; NM_022673) was cloned from rat brain by standard RT-PCR method. This fragment of $1.48 \mathrm{~kb}$ was inserted into pAAV2-CMV backbone plasmid (provided by Dr Guanping Gao, University of Massachusetts Medical School) with EcoRI and KpnI sites to construct pAAV-CMV-MeCP2. Positive clones of pAAV-CMV-MeCP2 were first identified by restriction endonuclease analysis and further confirmed by DNA sequencing. AAV-CMV-MeCP2 plasmids were transfected into $\mathrm{CHO}$ cells with Lipofectamine 2000 (Invitrogen) and cell samples were collected at 36 $\mathrm{h}$ after transfection. Western blot analysis was used to confirm overexpression of MeCP2 protein in transfected $\mathrm{CHO}$ cells. Then, pAAVCMV-MeCP2 was packaged into serotype 5 adeno-associated virus (AAV) vectors by the vector core at University of North Carolina at Chapel Hill. The construction of AAV-shRNA-GluA1 vector was described in details in our previous report (Cai et al., 2013). AAV-shRNAGluA1 $\left(5 \times 10^{9} \mathrm{GC} / 1 \mu \mathrm{l} / \mathrm{sites}\right), \mathrm{AAV}-\mathrm{MeCP} 2\left(2 \times 10^{9} \mathrm{GC} / 1 \mu \mathrm{l} / \mathrm{sites}\right)$ or control vector AAV-GFP $\left(2.5 \times 10^{9} \mathrm{GC} / 1 \mu \mathrm{l} /\right.$ sites $)$ was bilaterally microinjected into CeA (anteroposterior, $-2.2 \mathrm{~mm}$ from bregma; lateral, 4.0; dorsoventral, -8.0 from the skull), followed by a $3 \mathrm{~d}$ recovery period before intravenous catheterization.

Catheterization surgery. Under isoflurane anesthesia, a catheter (SAI, $11 \mathrm{~cm}$ in length, $0.1 \mathrm{~cm}$ outer diameter, and $0.06 \mathrm{~cm}$ inner diameter) was inserted into the right jugular vein and the other end of the catheter was routed subcutaneously to the back where it exited just posterior to the scapula. Rats were housed two per cage after catheter implantations. The catheter was flushed daily with gentamicin $(40 \mathrm{mg} / \mathrm{ml}, 0.5 \mathrm{ml})$ to maintain catheter patency and prevent infection. After postoperative recovery for 6-10 d, intraplantar injection of CFA or saline was made and $2 \mathrm{~d}$ later, the rat was allowed to MSA sessions.

MSA and morphine withdrawal. MSA sessions were started 11-15 d after CeA microinjection of the viral vectors. All MSA sessions were conducted during the light cycle at the same time every day. A syringe pump was connected to the catheter by quick connection systems (Strategic Applications). In rat group of MSA, pressing the active lever triggered an intravenous infusion of morphine ( 1 or $0.2 \mathrm{mg} / \mathrm{kg} /$ infusion $)$ in a volume of $0.05-0.1 \mathrm{ml}$ (based on rat weight) over $4 \mathrm{~s}$ on a FR1 schedule with illuminated cue light. Each infusion was followed by a $30 \mathrm{~s}$ timeout period during which all lever presses did not result in more infusions. Each MSA session lasted for $3 \mathrm{~h}$ with the total infusion number recorded in the $3 \mathrm{~h}$ period and was conducted once daily for $10 \mathrm{~d}$. Following $10 \mathrm{~d}$ stable MSA, persistence of the lever-pressing behavior for morphine seeking or extinction of MSA was examined by cessation of morphine administration (morphine withdrawal; Markou et al., 1993), during which pressing of the active lever resulted in an infusion of saline instead of morphine, accompanied by the illumination of the cue light that was previously paired with morphine infusion. The infusion number for saline after morphine withdrawal was recorded every other day for $13 \mathrm{~d}$. In a separate rat group of saline self-administration (SSA) for control, pressing of the active lever resulted in an infusion of saline with all other experimental procedures the same as the MSA group throughout the periods of MSA and morphine withdrawal. After the behavioral experiments, the CeA tissues were harvested from the rats that had undergone $13 \mathrm{~d}$ morphine withdrawal and control SSA rats after the same period for molecular analysis.

Western blots. A rat was deeply anesthetized by isoflurane and decapitated within 2-4 h after behavior experiment. The brain was cut in a vibratome in cold $\left(4^{\circ} \mathrm{C}\right)$ artificial CSF to obtain brain slices $(0.5 \mathrm{~mm}$ thick). Both sides of CeA, the nucleus accumbens (NAc), basolateral amygdala (BLA) and medial prefrontal cortex ( $\mathrm{mPFC}$ ) were punched out from the slices with a blunt-end syringe needle $(0.8 \mathrm{~mm}$ inner diameter), frozen in liquid nitrogen, and stored in a $-80^{\circ} \mathrm{C}$ freezer. Tissue homogenates were prepared with RIPA buffer (Cell Signaling Technology) and protein concentration was determined by BCA analysis (Thermo). Equal protein amount $(10 \mu \mathrm{g})$ of samples was used for immunoreactivity of GluA1 (1:200-500, Santa Cruz Biotechnology), GluA2 (1:600-1000, Millipore), MeCP2 (1:2000, Millipore), pERK (1:2000, Cell Signaling Technology), BDNF (1:500, Santa Cruz Biotechnology), and tubulin (1: 1000, Cell Signaling Technology). The immunopositive signals were quantified by Quantity One software (Bio-Rad) and levels of target proteins were normalized to tubulin.

ChIP. General chromatin immunoprecipitation (ChIP) method was described in our previous studies (Zhang et al., 2011, 2014a; Bie et al., 2012). Tissues were incubated in $1 \%$ formaldehyde for 12 min for DNA cross-link at room temperature and then quenched with $0.125 \mathrm{M}$ glycine 
A

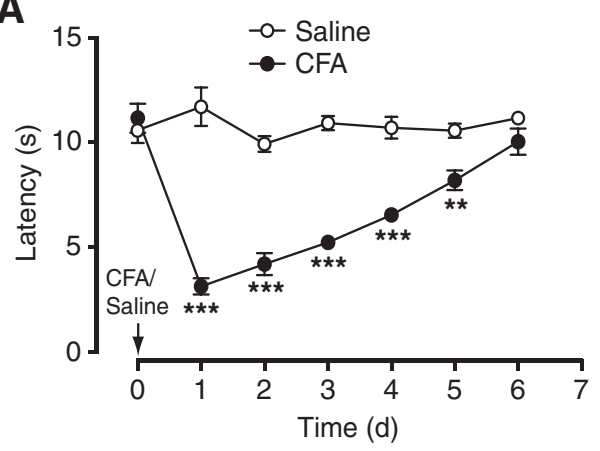

B

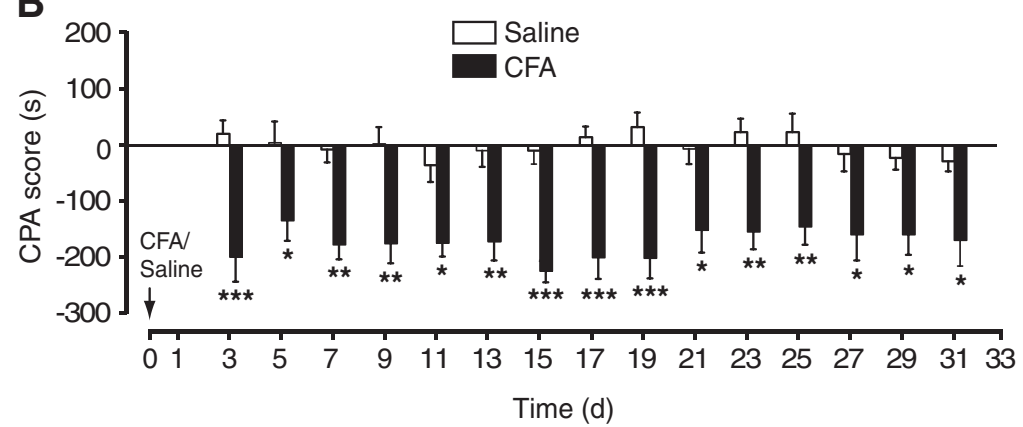

Figure 1. Time courses for the two dimensions of pain. $\boldsymbol{A}$, Sensitization of thermal pain of sensory dimension (hyperalgesia) measured by paw-withdrawal latencies in rats after an intraplantar injection of CFA $(n=6)$ or saline $(n=5)$ on day 0 (arrow). $\boldsymbol{B}$, Affective dimension of pain measured by CPA in conditioned rats after the same injection of (FA or saline ( $n=11$ each group) on day 0 (arrow; ${ }^{*} p<0.05,{ }^{* *} p<0.01,{ }^{* * *} p<0.001$; two-way ANOVA with Bonferroni post hoc test).

Statistic analysis. Simple comparisons between two groups were performed with unpaired Student's $t$ tests. Behavioral data were analyzed with one-way or two-way ANOVA for repeated measures followed by the Bonferroni post hoc test. Differences with $p<0.05$ were considered statistically significant. All statistical analyses were performed with the Prism software version 6 (GraphPad Software). Data are presented as mean \pm SEM.

\section{Results}

Persistent pain maintains morphineseeking behavior after morphine withdrawal

We first characterized the time course for sensory pain induced by intraplantar injection of CFA and for CFA-induced affective dimension of pain measured by the paradigm of CPA in rats. CFA significantly increased sensitivity to noxious thermal stimuli and this CFA-induced hyperalgesia peaked $1 \mathrm{~d}$ after CFA injection and lasted for $5 \mathrm{~d}$ compared with salineinjected control rats (time: $F_{(6,54)}=17.74$, $p<0.0001$; CFA: $F_{(1,9)}=211.0, p<$ 0.0001 ; interaction: $F_{(6,54)}=19.45, p<$ 0.0001 ; two-way ANOVA with Bonferroni post hoc test; Figure $1 A$ ). After place conditioning, the CFA-injected rats displayed strong CPA behavior, whereas the saline-injected rats showed no significant

for 5 min. After wash with PBS, samples were homogenized in lysis buffer (1\% SDS, 10 mm EDTA, 50 mm Tris, $\mathrm{pH} 8.1$ ) containing protease inhibitor (Sigma-Aldrich) and chromatins were sheared with Bioruptor sonicator for 35 cycles of $30 \mathrm{~s} \mathrm{ON} / 30 \mathrm{~s}$ OFF in a $4^{\circ} \mathrm{C}$ water bath. Average DNA fragment size in the range of $300-400 \mathrm{bp}$ was confirmed by agarose gel electrophoresis. For immunoprecipitation, $150 \mu \mathrm{l}$ of chromatin was diluted 1:10 in ChIP dilution buffer (0.01\% SDS, 1.1\% Triton X-100, 1.2 mм EDTA, $16.7 \mathrm{~mm}$ Tris- $\mathrm{HCl}, 167 \mathrm{~mm} \mathrm{NaCl}, \mathrm{pH} 8.1$ ) and $\sim 7 \%$ of the diluted sample was saved to serve as input controls. Before sample sonication, dynabeads protein A (Life Technologies) was incubated with MeCP2 antibodies (Cell Signaling Technology, no. 3456, $5 \mu$ l per sample) or IgG (Epigentek, $5 \mu$ l per sample) overnight at $4^{\circ} \mathrm{C}$ under constant rotation in blocking solution (0.5\% BSA in PBS). Following wash and resuspension of the antibody-bead conjugates, chromatin samples were added in antibody-bead mixtures and incubated for $16 \mathrm{~h}$ under constant rotation at $4^{\circ} \mathrm{C}$. After immunoprecipitation, the beads were washed at least six times ( 5 min each) with wash buffer ( $50 \mathrm{~mm}$ HEPES-KOH, $\mathrm{pH}$ 7.6, $500 \mathrm{~mm} \mathrm{LiCl,} 1$ mм EDTA, 1\% NP-40, 0.7\% Na-deoxycholate), one time with TE buffer (10 mM Tris-HCl, pH 8.1, 1 mM EDTA), and then eluted in $200 \mu$ l elution buffer (50 mu Tris-HCl, pH 8.1, 10 mm EDTA, $1 \% \mathrm{SDS})$. The elute was incubated at $65^{\circ} \mathrm{C}$ for $4 \mathrm{~h}$ to reverse the crosslink. The input DNA was diluted in elution buffer to a volume of $200 \mu \mathrm{l}$ and processed for cross-link reversal. Samples were then digested sequentially with $0.2 \mu \mathrm{g} / \mathrm{ml}$ RNase A for $2 \mathrm{~h}$ at $37^{\circ} \mathrm{C}$ and with $20 \mu \mathrm{g}$ of proteinase $\mathrm{K}$ for $30 \mathrm{~min}$ at $55^{\circ} \mathrm{C}$. DNA was extracted by phenol/chloroform/isoamyl alcohol (Fisher) and subjected to quantitative PCR (ABI 7000 Q-PCR) with primers specific to the promoter region of Grial gene encoding GluA1. The primer sequences were as follows: forward, CTGGCTGTCAGTCGGTGTT, reverse, CCCTCCCCTCCCTTCGATT. The quantitative real-time PCR data were analyzed by comparative $C t$ method. To control for variation between ChIP fractions, a $\Delta C t$ value was calculated according to the following formula: $\Delta C t \operatorname{MeCP} 2\left(\Delta C t_{\mathrm{IgG}}\right)=$ $C t_{\text {MeCP2 or IgG }}-\left(C t_{\text {Input }}-\log _{2}\right.$ (fraction of the input saved $\left.)-1\right)$. Data are presented as percentage input of each IP sample: percentage input $=2-$ $(\Delta C t)$. IgG was used as a negative control for nonspecific binding to the beads. change in behavior of place preference (time: $F_{(14,280)}=0.58, p=$ 0.8764; CFA: $F_{(1,20)}=54.14, p<0.0001$; interaction: $F_{(14,280)}=$ $0.73, p=0.7428$; Figure $1 B)$. Importantly, we found that the CPA lasted for at least $31 \mathrm{~d}$ (the longest time point measured), long after the hypersensitivity of sensory pain had fully resolved. This suggests that the affective dimension of pain may significantly outlast the sensory pain, indicating a long-lasting effect of pain on the affective and emotional state of the animal.

To determine the impact of pain on motivational effects of opioids, we examined behaviors of morphine intake and morphine seeking in a rat model of MSA under this CFA-induced pain condition. We first used a dose of morphine $(1 \mathrm{mg} / \mathrm{kg} / \mathrm{infu}-$ sion, i.v.) that has been commonly used in previous studies of opioid addiction in rodents (Norwood et al., 2003; SánchezCardoso et al., 2009). We found that stable MSA behavior was maintained at similar levels in CFA- and saline-injected rats, indicating the establishment of steady behavior of morphine reinforcement (time: $F_{(9,135)}=6.237, p<0.0001$; treatment: $F_{(2,15)}=$ $11.80, p=0.0008$; interaction: $\left.F_{(18,135)}=8.813, p<0.0001\right)$; and it showed no significant difference in the number of lever pressing in those rats regardless of the pain condition (Fig. 2A). Upon morphine withdrawal when pressing of the active lever resulted in an infusion of saline instead of morphine, both groups of rats displayed a significantly increased number of lever pressing for saline and maintained this behavior similarly over a 2 week period at a higher level than that before morphine withdrawal (time: $F_{(6,90)}=4.613, p=0.0004$; treatment: $F_{(2,15)}=34.82, p<$ 0.0001 ; interaction: $F_{(12,90)}=0.9705, p=0.4827$; Figure $\left.2 A\right)$. In a separate rat group of SSA, the lever-pressing behavior soon declined and remained at a minimal level throughout the entire experiment period due to nonreinforcing saline. Consistently, rats in pain group maintained discriminative ability in lever pressing 
by pressing the active lever more frequently than the inactive lever during morphine withdrawal (time: $F_{(6,60)}=3.19, p=0.0087$; lever pressing: $F_{(1,10)}=95.14, p<0.0001$; interaction: $\left.F_{(6,60)}=1.85, p=0.1053\right)$, whereas pressing of the active lever was similar in pain and control groups (time: $F_{(6,54)}=6.03, p<0.0001$; CFA: $F_{(1,9)}=$ $1.51, p=0.2509$; interaction: $F_{(6,54)}=2.37$, $p=0.0417$; Figure $2 B$ ). This increased magnitude of lever-pressing behavior after morphine withdrawal represents the typical behavior of drug seeking and drug craving reported previously in animal models of drug addiction (Grimm et al., 2001; Conrad et al., 2008). Therefore, it appears that, at this morphine dose, the pain condition does not have a significant impact on the behavioral magnitude of morphine intake and morphine seeking upon morphine withdrawal under these experimental conditions.

Considering that this MSA dose of 1 $\mathrm{mg} / \mathrm{kg}$ in animals is rather high compared with that typically for recreational use and abuse in humans (Comer et al., 2008; Stoops et al., 2010), and that this high dose with near maximum responses in MSA and morphine withdrawal may prevent the revelation of an enhancing effect of pain due to a ceiling effect, we then used a lower dose of morphine $(0.2 \mathrm{mg} / \mathrm{kg} / \mathrm{infu}-$ sion, i.v.) for MSA. After initial decrease, the daily infusion number of MSA was again maintained at a steady and similar level in CFA- and saline-injected rats, indicating the rewarding effect of morphine at this dose, regardless of pain (time: $F_{(9,108)}=$ 6.048, $p<0.0001$; CFA: $F_{(1,12)}=0.08842$, $p=0.7713$; interaction: $F_{(9,108)}=0.8257$, $p=0.5938$; Figure $2 C$ ). However, upon morphine withdrawal, whereas salineinjected rats displayed gradually extinguished morphine-seeking behavior over a 2 week period, CFA-injected rats largely maintained the lever-pressing behavior, even though saline was delivered as a result, at a level similar to the prewithdrawal level for at least 2 weeks ( $24 \mathrm{~d}$ after CFA injection, the longest time tested; time: $F_{(6,72)}=0.5453, p=0.7720$; CFA: $F_{(1,12)}=$ 11.27, $p=0.0057$; interaction: $F_{(6,72)}=$ $2.354, p=0.0393$; Figure $2 C$ ). Accordingly, number of pressing of active lever in pain rats was significantly higher than that of their inactive lever-pressing (time: $F_{(6,72)}=$ 0.43, $p=0.8543$; lever pressing: $F_{(1,12)}=$ 20.48, $p=0.0007$; interaction: $F_{(6,72)}=0.29$, $p=0.9420)$, and than that of active lever-

pressing in saline control group during morphine withdrawal (time: $F_{(6,72)}=1.01, p=0.4253$; CFA: $F_{(1,12)}=6.34, p=0.0270$; interaction: $F_{(6,72)}=0.86, p=0.5298$; Figure $\left.2 D\right)$. To prevent a potential confounding effect of the cue light used in food reward
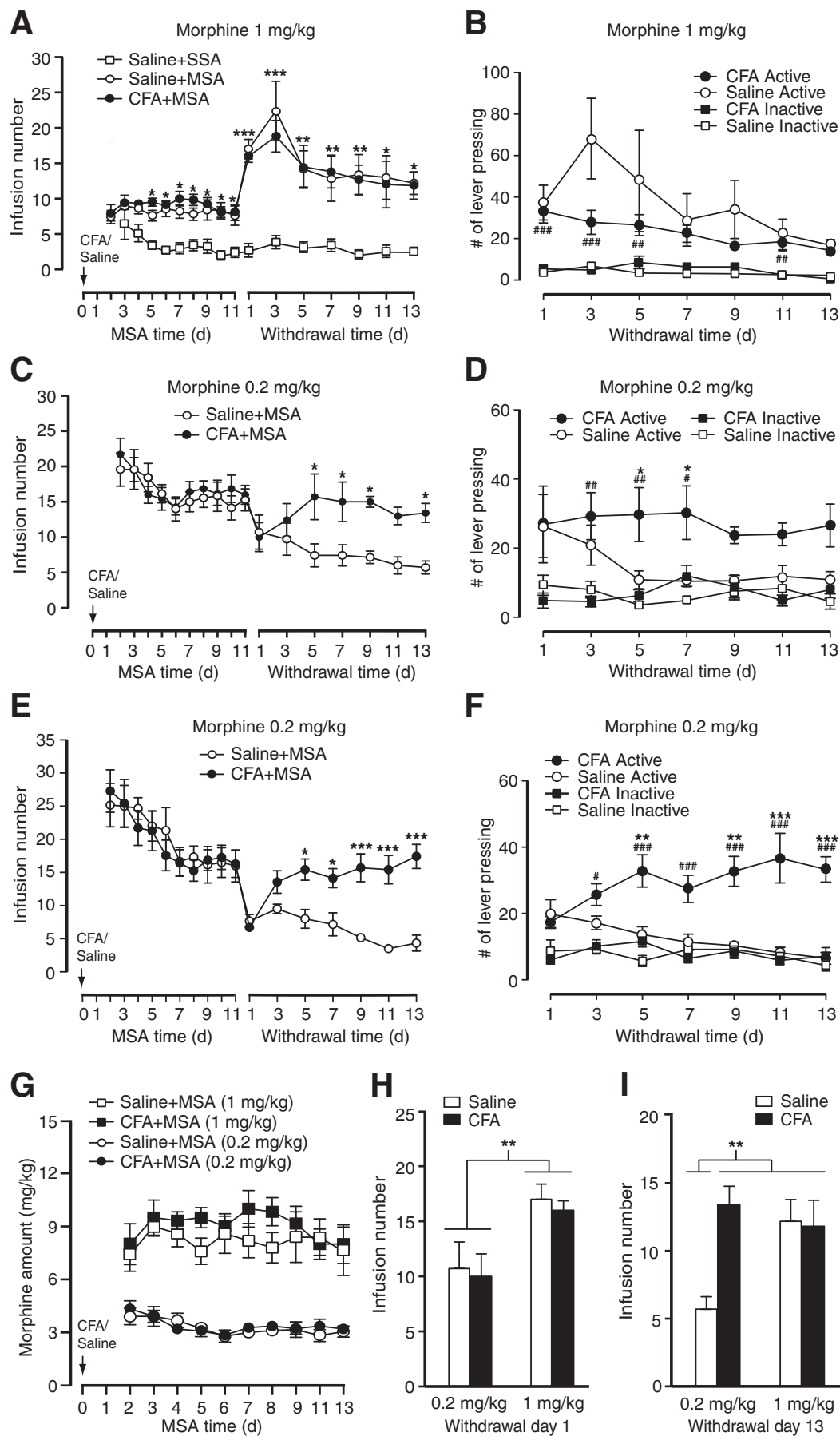

Figure 2. Persistent pain maintains morphine-seeking behavior after withdrawal from self-administered morphine. $A$, Daily infusion numbers ofSSAin saline-injected rats (saline $+S S A, n=7$ ) andMSA in saline-(saline + MSA, $n=5$ ), and CFA-(CFA + MSA, $n=6$ ) injected rats beforeand after withdrawal from a high morphine dose (1 mg/kg/infusion). CFA or saline was injected on day 0 (arrow), MSA started on day 2 and morphine withdrawal started on day 12 (withdrawal day 1). $\boldsymbol{B}$,Number of pressing of activeand inactiveleversfordatashownin $\boldsymbol{A}$ during morphinewithdrawal (\#p <0.05, \#\#p<0.01,\#\#p <0.001, activevsinactiveleverpressing in (FAgroups).C, Infusionnumbers ofMSA rats afterinjection of saline or CFA ( $n=7$ each group) before and after withdrawal from a low morphine dose $(0.2 \mathrm{mg} / \mathrm{kg} / \mathrm{infusion}) . \boldsymbol{D}$, Number of pressing of active and inactive levers fordatashownin Cduringmorphinewithdrawal ( ${ }^{*}$ CFAvssalinein pressing of activelever; \#activevs inactiveleverpressing in CFAgroups).E,F,Similar experiments to thosein C, D butwithoutuse of a cuelightinfoodreward beforeMSA. G, Total dailyMSA dosagefor saline-and CFA-injected rat groups in $\boldsymbol{A}$ (high morphine dose, squares) and in $\boldsymbol{B}$ (low morphine dose, circles). $\boldsymbol{H}, \boldsymbol{I}$, Comparison of infusion numbers between high and low morphine doses from data in $\boldsymbol{A}$ and $\boldsymbol{C}$ on withdrawal day $1(\boldsymbol{H})$ and day 13 ( $\boldsymbol{I}$; Student'st test and two-way ANOVA with Bonferroni post hoc test).

training before MSA in above experiments, we performed similar experiments with the low dose morphine but without the cue light in food reward. Similar results were obtained in the infusion number of MSA with no difference between pain and saline 
A

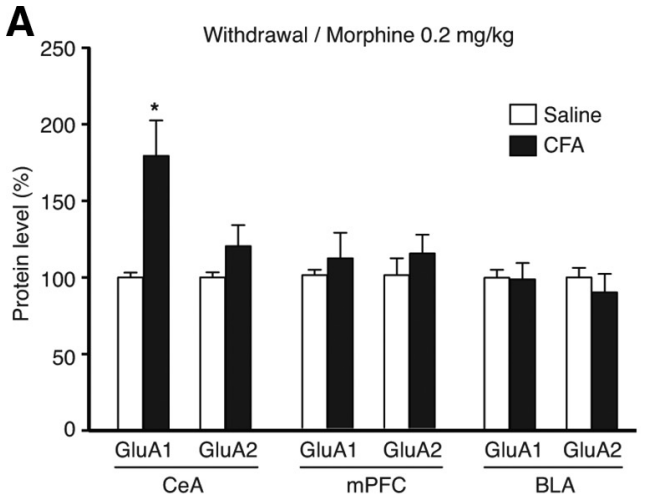

B
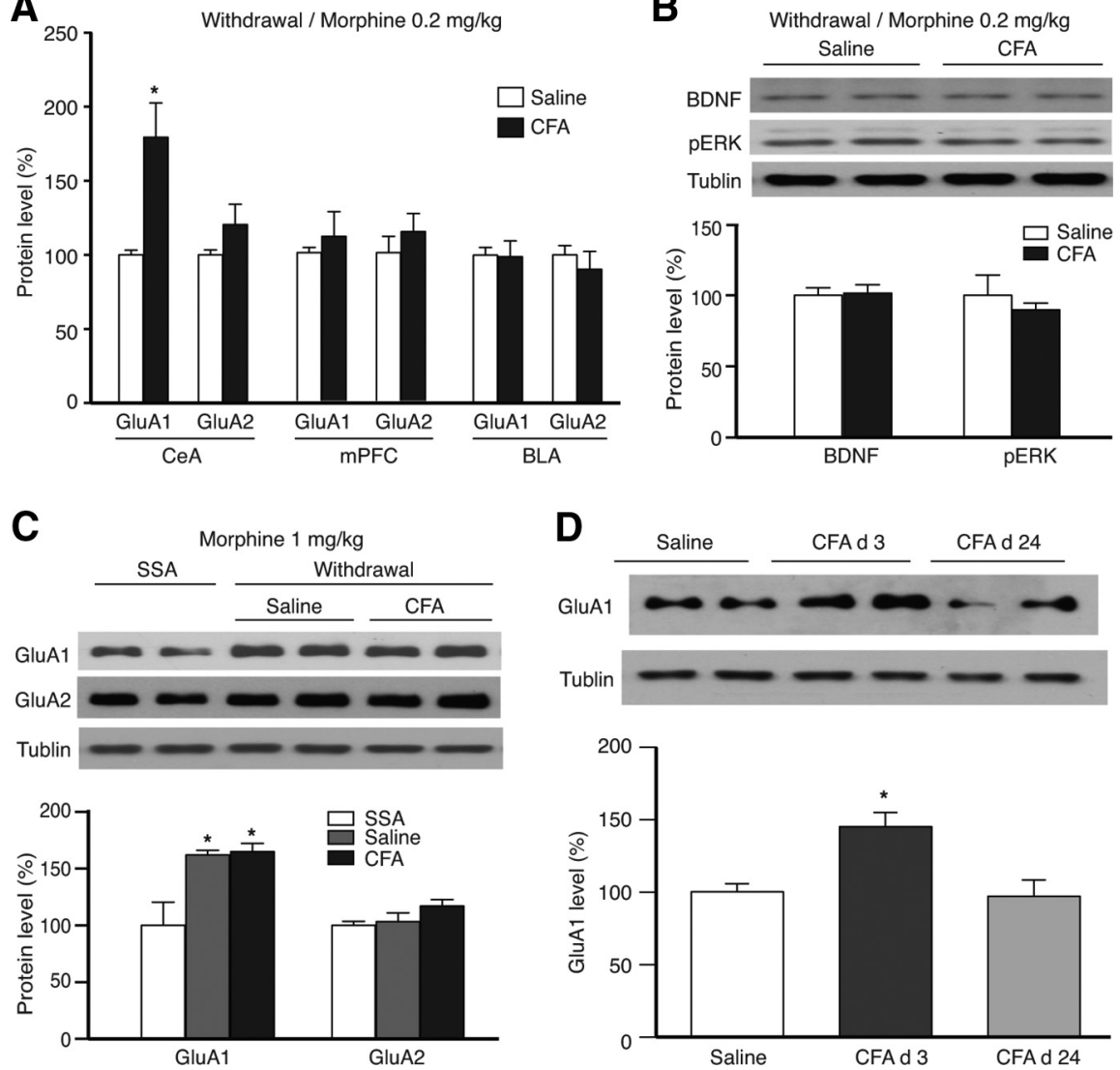

D
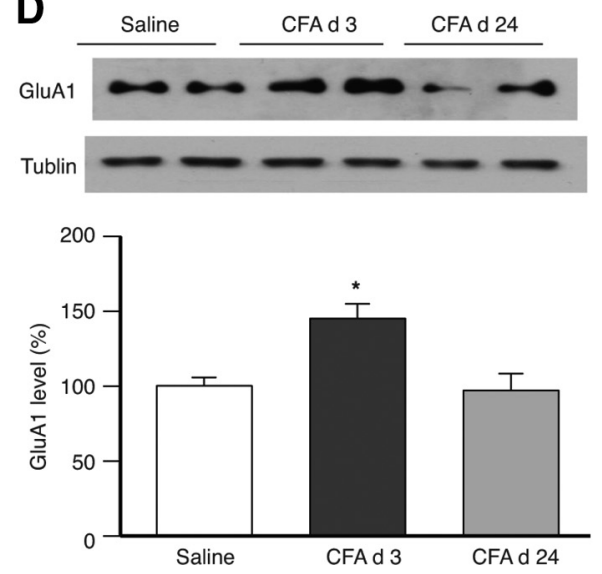

Figure 3. Morphine withdrawal selectively increases GluA1 protein level in CeA. $A$, Normalized protein levels of GluA1 and GluA2 in the three brain sites in saline- $(n=4)$ and CFA- $(n=4)$ injected rats withdrawn from self-administered morphine $(0.2$ $\mathrm{mg} / \mathrm{kg} /$ infusion) for $13 \mathrm{~d}$. B. Western blots (top) and normalized results (bottom) of BDNF and pERK proteins in the CeA of MSA rats of control $(n=4)$ and pain $(n=4)$ groups after $13 \mathrm{~d}$ of morphine withdrawal. C, Western blots data of GluA1 and GluA2 levels normalized to tubulin in the CeA of naive SSA rats $(n=4)$ and MSA rats of control (saline, $n=4)$ and pain (CFA, $n=4)$ groups withdrawn from the high morphine dose (1 $\mathrm{mg} / \mathrm{kg} /$ infusion) for $13 \mathrm{~d}$. D. Western blots data of CeA GluA1 in saline-injected rats $(n=5)$ and in CFA-injected rats $(n=4)$ at 3 and $24 \mathrm{~d}$ after CFA-injection (Student's $t$ test and one-way ANOVA with Bonferroni post hoc test).

groups (time: $F_{(9,99)}=9.537, p<0.0001$; CFA: $F_{(1,11)}=0.0426$, $p=0.8403$; interaction: $\left.F_{(9,99)}=0.5166, p=0.8595\right)$; after morphine withdrawal, the pain rats, but not control rats, similarly maintained the morphine-seeking behavior (time: $F_{(6,66)}=$ $2.382, p=0.0383$; CFA: $F_{(1,11)}=61.65, p<0.0001$; interaction: $F_{(6,66)}=5.951, p<0.0001$; Figure $\left.2 E\right)$. This heightened behavior of morphine seeking in pain rats also was achieved by more frequent pressing of the active lever (time: $F_{(6,66)}=0.42, p=0.86$; CFA: $F_{(1,11)}=44.47, p<0.0001$; interaction: $F_{(6,66)}=4.42$, $p=0.0008$ ), and by selective pressing of the active lever (time: $F_{(6,72)}=2.56, p=0.0264$; lever pressing: $F_{(1,12)}=69.81, p<$ 0.0001 ; interaction: $F_{(6,72)}=2.07, p=0.0669$; Figure $\left.2 F\right)$. Thus, the cue light used in food reward appears to have little effect on the animal's behavioral response of MSA or morphine withdrawal.

We compared the above data of the pain effects between the high and low dose of morphine. For the total amount of morphine intake per MSA session, rats of both pain and control groups consumed considerably more morphine at the high dose than at the low dose, indicating that higher doses exacerbate opioid consumption (time: $F_{(9,210)}=0.9070, p=0.5200$; treatment: $F_{(3,210)}=227.9, p<0.0001$; interaction: $F_{(27,210)}=0.6732, p=$ 0.8891; Figure $2 G$ ). However, at both high and low doses, rats consumed similar amount of morphine regardless of pain (Fig. $2 G$ ). Comparison of morphine withdrawal data showed that the high morphine dose enhanced the magnitude of morphine-seeking behavior at the beginning of morphine withdrawal, similarly regardless of pain (morphine dose: $F_{(1,21)}=10.09, p=0.0045$; CFA: $F_{(1,21)}=$ $0.1965, p=0.6621$; interaction: $F_{(1,21)}=$ $0.0055, p=0.9415$; Figure $2 H)$. However, after $13 \mathrm{~d}$ of morphine withdrawal, pain heightened this morphine-seeking behavior to a magnitude similar to that of the high morphine dose (morphine dose: $F_{(1,21)}=2.843, p=0.1066$; CFA: $F_{(1,21)}=6.418, p=0.0193$; interaction: $F_{(1,21)}=7.763, p=0.0111$; Figure $\left.2 I\right)$.

Together, these results support the notion that pain experience may maintain behaviors of opioid seeking after withdrawal from submaximal opioid doses for a long period of time. Given the long lasting CFA-induced CPA of affective pain, it is possible that this heightened opioidseeking behavior is driven at least partially by positive reinforcing effects of morphine to alleviate the aversive emotion associated with the pain experience. Therefore, we used this low morphine dose in all following behavioral experiments of MSA and morphine withdrawal and molecular analysis unless specified otherwise.

\section{GluA1 in CeA promotes morphine- seeking behavior}

Considering the important role of AMPAR GluA1 subunits in synaptic plasticity for learning and memory and in promoting behavioral responses to drugs of abuse and pain, we determined whether GluAl in CeA was involved in this heightened opioidseeking behavior. In CeA tissues taken from rats after $13 \mathrm{~d}$ of morphine withdrawal, Western blotting analysis showed that the protein level of GluA1, but not GluA2, was significantly increased in rats of pain group that maintained morphine-seeking behavior compared with that of control group with the behavior diminished ( $p<0.05$; Fig. $3 A)$. In contrast, GluA1 levels in BLA and mPFC were unchanged in those rats of pain group (Fig. $3 A$ ). We also determined protein levels of brain-derived neurotrophic factor (BDNF) and phosphorylated extracellular signal-regulated kinase (pERK), two proteins previously reported to paly a role in opioid craving (Li et al., 2008; Vargas-Perez et al., 2009). Our data showed that pain did not change the level of either BDNF or pERK in the CeA of these morphine-withdrawn rats (Fig. 3B). At the high morphine dose, for comparison, similar increase in CeA GluA1 was observed in $13 \mathrm{~d}$ withdrawn rats of both pain and control groups that both maintained the morphine-seeking behavior compared with SSA rats $(p<0.05$; Fig. $3 C$ ). We then determined the effect of pain itself on the CeA GluA1 level. In CFA-injected rats, we found that CeA GluAl was significantly increased $3 \mathrm{~d}$ after CFA-injection (one-way ANOVA: $F_{(2,10)}=$ $12.24, p=0.0021)$, but returned to control level $24 \mathrm{~d}$ after CFA injection (Fig. $3 D$ ), indicating that the GluAl increase in rats of morphine withdrawal for $13 \mathrm{~d}$ ( $24 \mathrm{~d}$ after CFA injection) was due to morphine withdrawal, but not to pain itself. Thus, it 
appears that selective upregulation of CeA GluAl proteins with increased GluA1/GluA2 ratio, which strengthens synaptic activity of AMPARs through increased number of GluA2lacking AMPARs in CeA (Cai et al., 2013), may play an important role in the heightened behavior of opioid seeking after morphine withdrawal.

To further determine the GluA1 role, we used an AAV vector expressing a short-hairpin interfering RNA against GluAl (AAVsh-GluA1) to locally knockdown GluA1 by microinjection of the vector into CeA as we reported before (Cai et al., 2013). AAVsh-GluA1 specifically reduced protein level of GluA1, but did not alter GluA2 protein level in CeA compared with control rats receiving CeA microinjection of AAV-GFP vector $(p<0.05$; Fig. $4 A)$. We then determined the pain effect on the morphineseeking behavior after withdrawal with the viral knockdown of CeA GluA1 in CFA-injected rats. Knockdown of CeA GluA1 had no effect on the level of daily morphine infusions (time: $F_{(9,99)}=$ $2.908, p=0.0043$; sh-GluA1: $F_{(1,11)}=0.0317, p=0.8619$; interaction: $F_{(9,99)}=0.3179, p=0.9674$; Figure $\left.4 B\right)$. However, after morphine withdrawal, the GluA1 knockdown dramatically decreased the number of infusions with the morphine-seeking behavior gradually ceased (time: $F_{(4,44)}=1.541, p=0.2069$; shGluA1: $F_{(1,11)}=26.40, p=0.0003$; interaction: $F_{(4,44)}=3.170$, $p=0.0225$; Figure $4 B)$, similar to those saline-injected control rats without pain (Fig. $2 C$ ), whereas the control vector-injected rats maintained the behavior of daily infusions. Accordingly, rats of sh-GluAl group showed gradually diminished pressing of active lever to control levels upon morphine withdrawal (sh-GluA1 vs GFP: time: $F_{(4,44)}=12, p<0.0001$; treatment: $F_{(1,11)}=5.44$, $p=0.0397$; interaction: $F_{(4,44)}=3.48, p=0.0148$ ), whereas rats of GFP control group maintained their pressing of active lever (active vs inactive: time: $F_{(4,40)}=3.75, p=0.0111$; lever pressing: $F_{(1,10)}=38.32, p=0.0001$; interaction: $F_{(4,40)}=1.48, p=0.2256$; Figure $4 C$ ). Together, these results suggest that amygdalar GluA1 plays an important role in maintaining morphine-seeking behavior induced by pain experience after morphine withdrawal.

\section{$\mathrm{MeCP} 2$ represses CeA Gria1 expression}

Given our recent findings that the transcriptional regulator $\mathrm{MeCP} 2$ in CeA critically regulates interactions of pain and opioid reward (Zhang et al., 2014a), we were wondering the regulating role of MeCP2 in the expression of Grial gene encoding GluA1 in $\mathrm{CeA}$ and in the pain-induced maintenance of morphine-seeking behavior after morphine withdrawal. We found that, on withdrawal day 1, the CeA GluA1 level was not different between saline- and CFA-injected rats; and neither changed was CeA level of $\mathrm{MeCP} 2$ protein (Fig. $5 A$ ). However, on withdrawal day 13 when CeA GluA1 protein was significantly upregulated, CeA level of $\mathrm{MeCP} 2$ protein was significantly decreased in those morphinewithdrawn rats of pain group $(p<0.05$; Fig. $5 B)$. This indicates the possibility that MeCP2 represses Grial expression and this reduced $\mathrm{MeCP} 2$ function results in de-repression of Grial and increase in CeA GluA1.

To test the hypothesis that $\mathrm{MeCP} 2$ directly represses Grial in $\mathrm{CeA}$, we performed $\mathrm{ChIP}$ assays to determine whether MeCP2 as a transcriptional regulator directly binds to the promoters of Grial gene. Analysis of a $5 \mathrm{~kb}$ region upstream of the transcription start site (TSS) on Grial gene revealed one CpG-rich region located between -275 and -61 proximal to TSS (214 bp, GC content $=55 \%)$. We found that MeCP2 was significantly enriched at this promoter region of Grial in CeA of naive rats compared with nonspecific IgG control $(p<0.001$; Fig. $6 A)$. Moreover, this MeCP2 binding was significantly attenuated in
A
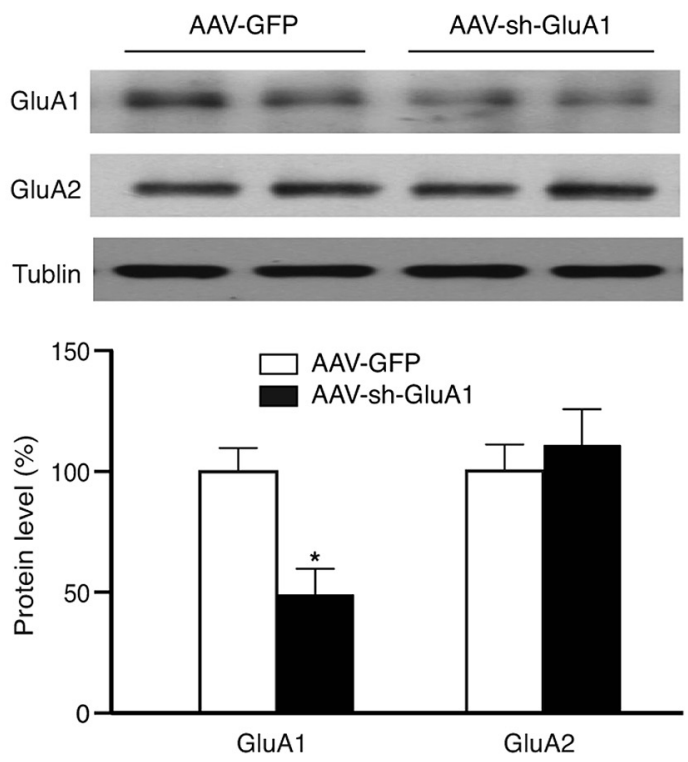

B

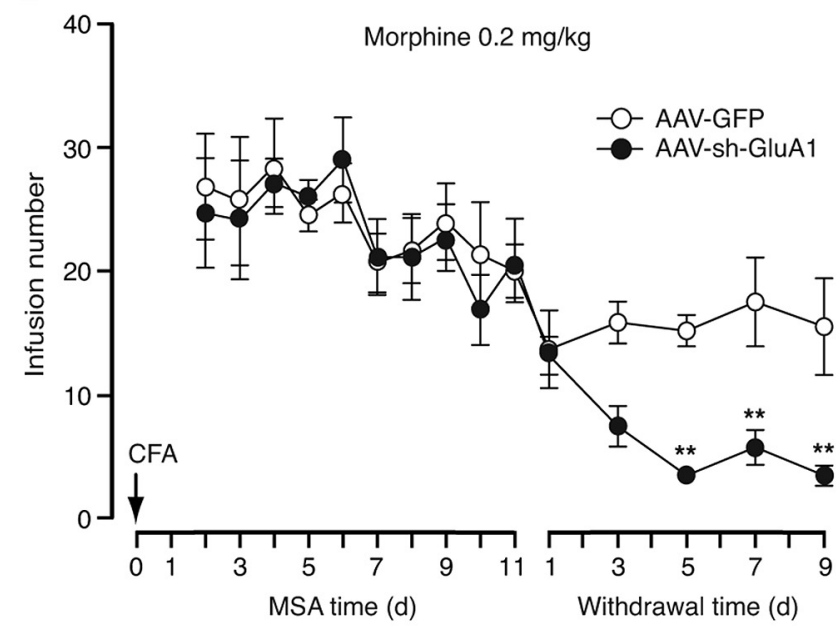

C

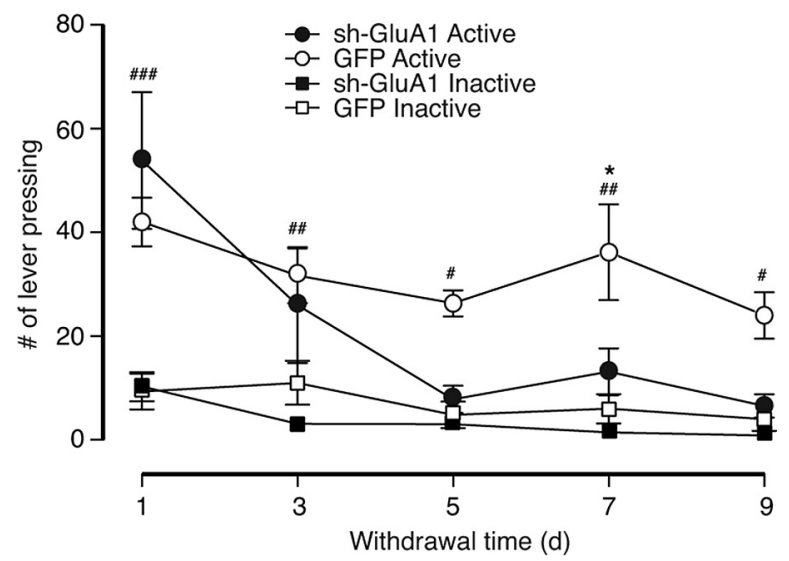

Figure 4. Viral knockdown of GluA1 in CeA reverses pain-induced maintenance of morphine-seeking behavior after morphine withdrawal. $A$, Western blots data of GluA1 and GluA2 proteins in the CeA of rats after bilateral microinjection of the AAV vector expressing GFP (AAV-GFP, $n=4$ ) or the AAV vector expressing a short-hairpin interfering RNA against GluA1 (AAV-sh-GluA1, $n=4$ ) into the CeA. $\boldsymbol{B}, \boldsymbol{C}$, Infusion numbers $(\boldsymbol{B})$ and pressing of active and inactive levers ( $C$ ) in rats injected with CFA (arrow) with CeA microinjection of AAV-GFP $(n=6)$ or AAV-sh-GluA1 ( $n=7$ ) before (MSA at $0.2 \mathrm{mg} / \mathrm{kg} /$ infusion) and after morphine withdrawal ( ${ }^{*}$ GFP vs sh-GluA1 in pressing of active lever; \#active vs inactive lever pressing in GFP groups; Student's $t$ test and two-way ANOVA with Bonferroni post hoc test). 
A
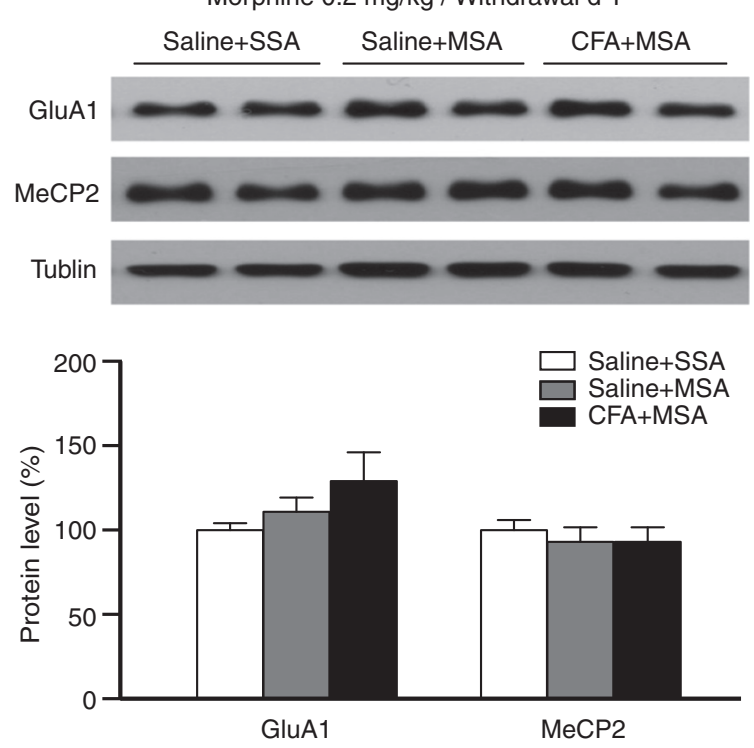

B
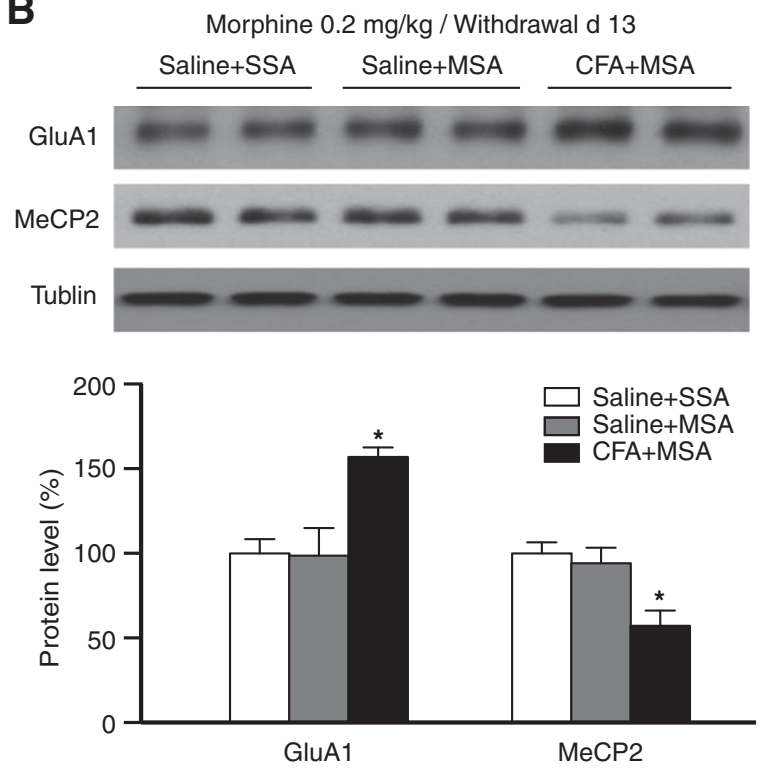

Figure 5. GluA1 increase is correlated to decrease in MeCP2 in CeA after morphine withdrawal. $A, B$, Western blots data of GluA1 and MeCP2 proteins in the CeA of saline-injected SSA rats $(n=4)$ and MSA rats injected with saline $(n=4)$ or CFA $(n=4)$ on morphine withdrawal day $1(n=4, \boldsymbol{A})$ and day 13 ( $n=4$, $\boldsymbol{B}$; one-way ANOVA with Bonferroni post hoc test).

the CeA of CFA-injected rats after $13 \mathrm{~d}$ morphine withdrawal $(p<0.01$; Fig. $6 B)$. These data support the notion that MeCP2 may act as a transcriptional repressor on Grial and persistent pain decreased this MeCP2 repression, leading to de-repression of Grial.

To verify this Grial-repressing function of $\mathrm{MeCP} 2$, we constructed AAV-MeCP2 vector to overexpress MeCp2 locally in CeA by microinjection of the vector into the CeA of naive rats. Quantitative analysis with Western blots showed that microinjection of AAV-MeCP2 into the CeA significantly raised the MeCP2 protein level in CeA $(p<0.05$; Fig. $6 C)$. In addition, overexpression of MeCP2 also concurrently reduced GluA1 protein level in CeA $(p<0.05$; Fig. $6 C)$ and significantly increased MeCP2 binding to the Grial promoter (Student's $t$ test: $t_{(1,6)}=3.716, p=$ 0.0099; Fig. 6B). Immunohistochemical images also showed that
A
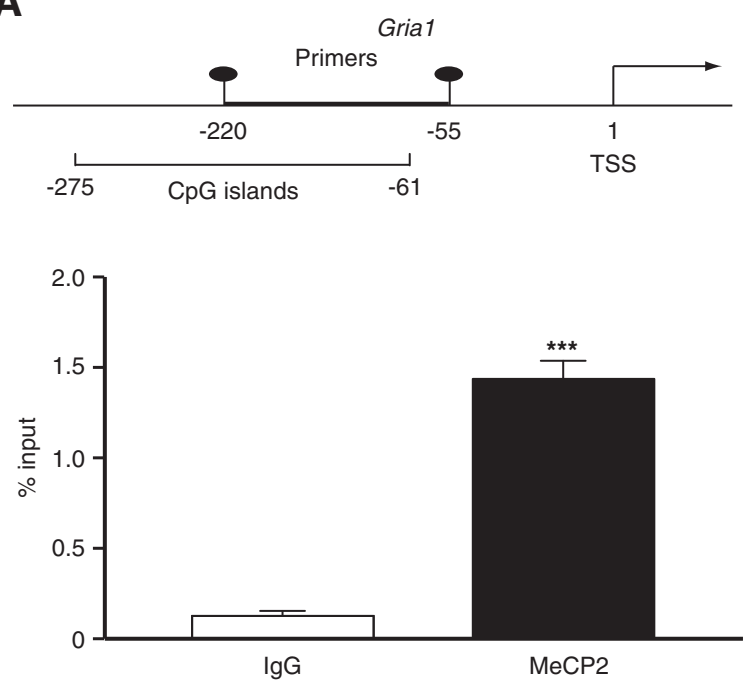

B
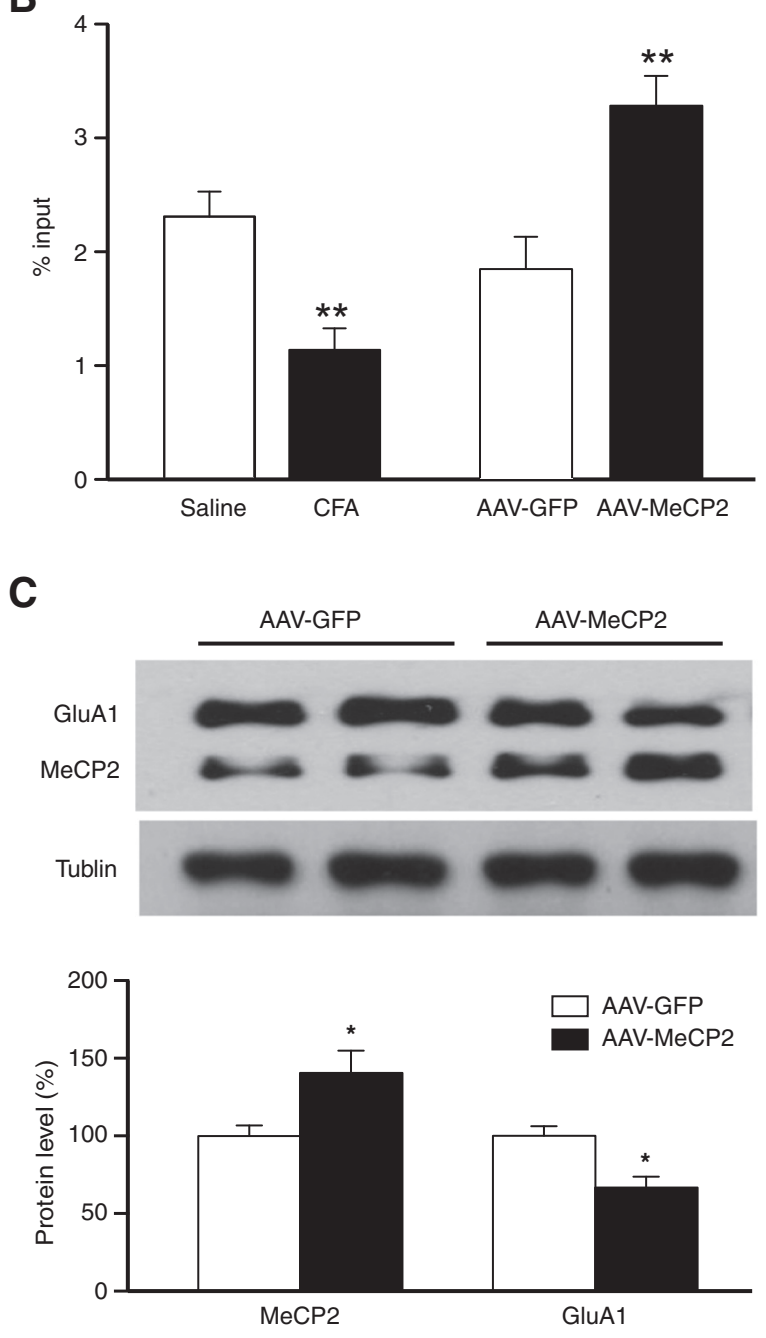

Figure 6. Pain regulation of $\mathrm{GluA} 1$ is mediated by direct $\mathrm{MeCP} 2$ repression of Gria 1 expression in CeA. $A$, Top, Schematic illustration of $\mathrm{PG}$-rich promoter region of Gria1 gene and the region targeted by the primers upstream of the TSS. Bottom, MeCP2 enrichment in the Gria 1 promoter region in naive rats $(n=4) . B, M e C P 2$ binding to the Gria 1 promoter region in the CeA of rats injected with saline $(n=4)$ or CFA $(n=4)$ after $13 \mathrm{~d}$ withdrawal from MSA $(0.2 \mathrm{mg} / \mathrm{kg} /$ infusion), and in naive rats with CeA microinjection of AAV-GFP or AAV-MeCP2 ( $n=4$ samples from 8 rats each group). C, Western blots data of GluA1 and MeCP2 proteins in the CeA of naive rats with CeA microinjection of AAV-GFP $(n=4)$ or AAV-MeCP2 ( $n=4$; Student's $t$ test). 
$\mathrm{AAV}-\mathrm{MeCP} 2$ injected into the CeA clearly upregulated $\mathrm{MeCP} 2$ in the CeA and the merged images of GFP and MeCP2 demonstrated the colocalization of the GFP-expressing vector and MeCP2 after CeA microinjection of AAV-MeCP2 mixed with AAV-GFP, indicating exogenous overexpression of MeCP2 via the AAV vector (Fig. 7). These results support a Grial-reppressing role of $\mathrm{MeCP} 2$ in CeA.

\section{Overexpression of $\mathrm{CeA} \mathrm{MeCP} 2$ reverses morphine-seeking behavior}

Next, we determined the behavioral effect of CeA MeCP2 overexpression on morphine-seeking behavior in CFA-injected rats after morphine withdrawal. Intra-CeA microinjection of AAVMeCP2 did not alter the daily MSA when compared with AAVGFP vector-injected rats (time: $F_{(9,108)}=3.116, p=0.0023$; AAV-MeCP2: $F_{(1,12)}=0.0095, p=0.9239$; interaction: $F_{(9,108)}=$ $0.4544, p=0.9018$; Figure $8 A$ ). After withdrawal for $11 \mathrm{~d}$, the control rats with CeA microinjection of GFP vector maintained the morphine-seeking behavior by continued selective pressing of active lever (active vs inactive: time: $F_{(5,50)}=3.61, p=0.0073$; lever pressing: $F_{(1,10)}=20.63, p=0.0001$; interaction: $F_{(5,50)}=$ $1.13, p=0.3574$; Figure $8 A, B$ ), similar to those CFA-injected rats without the vector injection (Fig. $2 C, D$ ). However, CeA-injected AAV-MeCP2 remarkably reversed the morphine-seeking behavior (AAV-MeCP2 vs AAV-GFP: time: $F_{(5,60)}=1.135, p=0.3521$; AAV-MeCP2: $F_{(1,12)}=11.57, p=0.0053$; interaction: $F_{(5,60)}=$ $2.791, p=0.0248$; Figure $8 A$ ), and reduced the pressing of active lever to control levels (AAV-MeCP2 vs AAV-GFP: time: $F_{(5,55)}=$ $1.35, p=0.2559$; treatment: $F_{(1,11)}=10.67, p=0.0075$; interaction: $F_{(5,55)}=3.38, p=0.0098$; Figure $\left.8 B\right)$. To confirm the viral effect of MeCP2 overexpression and consequent effect on GluA1 reduction in the above behavioral experiments, we harvested the CeA tissues from those rats afterward on withdrawal day 11 and examined protein levels of MeCP2 and GluA1. Our Western blot data showed that those CFA-injected rats with CeA microinjection of AAV-GFP displayed a significantly lower level of MeCP2 $(p<0.01)$ and elevated GluA1 level $(p<0.05)$, and this MeCP2 reduction and GluAl upregulation were completely reversed in those CFA-injected rats with CeA microinjection of AAVMeCP2 ( $p<0.001$; Fig. $8 C)$. Furthermore, in separate groups of CFA- or saline-injected rats, MeCP2 binding to the Grial promoter was significantly reduced by the pain condition after $11 \mathrm{~d}$ morphine withdrawal $(p<0.01$; Fig. $8 D)$, indicating derepression of Grial. For comparison, in rats withdrawn from the high morphine dose, MeCP2 binding to Grial was also significantly reduced regardless of pain $(p<0.001$; two-way ANOVA: morphine dose: $F_{(1,10)}=45.70, p<0.0001$; CFA: $F_{(1,10)}=13.45$, $p=0.0043$; interaction: $F_{(1,10)}=5.730, p=0.0377$; Figure $\left.8 D\right)$, as both of the control and pain groups at the high morphine dose maintained the morphine-seeking behavior after morphine withdrawal (Fig. 2A). These results further support the idea that reduced $\mathrm{MeCP} 2$ repression of Grial results in GluA1 upregulation in CeA after morphine withdrawal, leading to the maintained morphine-seeking behavior.

\section{Discussion}

In this study, we have shown molecular and behavioral evidence that persistent inflammatory pain maintains morphine-seeking behavior in rats after withdrawal from self-administered morphine at a submaximal dose by GluA1 upregulation in CeA. Our results suggest that $\mathrm{MeCP} 2$ transcriptionally represses Grial expression in $\mathrm{CeA}$ and reduction in this $\mathrm{MeCP} 2$ function causes de-repression of Grial and consequently GluA1 upregulation, which may contribute to the maintenance of morphine-seeking behavior after morphine abstinence.

$\mathrm{MeCP} 2$ is a global transcriptional regulator and genome-wide expression analysis indicates that $\mathrm{MeCP} 2$ can activate or repress transcription of many target genes (Chahrour et al., 2008). However, only a few genes have been reported to be directly regulated by MeCP2 (Guy et al., 2011; Zhang et al., 2014a). Emerging evidence suggests that Grial is one of those genes regulated by MeCP2. MeCP2 deficiency increases Gria1 transcription in cultured mouse astrocytes (Yasui et al., 2013), whereas MeCP2overexpressing mice display reduced GluAl mRNA level in hypothalamus (Chahrour et al., 2008). A recent study in rat striatum shows that chronic methamphetamine-induced GluA1 decrease is associated with increased enrichment of MeCP2 on Grial promoters (Jayanthi et al., 2014). In line with these reports, the present study demonstrates that viral overexpression of $\mathrm{MeCP} 2$ in CeA decreases CeA level of GluA1 proteins likely via direct repression of Grial expression. Importantly, we also show that pain may decrease recruitment of $\mathrm{MeCP} 2$ onto Grial promoters in CeA and reduce MeCP2 repression of Grial after opioid withdrawal, leading to GluA1 upregulation and contributing to the sustained opioid-seeking behavior in rats with pain experience. Acting as a transcriptional repressor, $\mathrm{MeCP} 2$ mediates gene silencing by recruiting other corepressors including Sin $3 \mathrm{~A}$ and histone deacetylases in the transcription complex (Jones et al., 1998; Nan et al., 1998).

$\mathrm{MeCP} 2$ is increasingly implicated in the epigenetic mechanisms of several neurological diseases including drug addiction and chronic pain. Studies of drug addiction generally show a promoting role of $\mathrm{MeCP} 2$ in motivational effects of drugs of abuse. MeCP2 in striatum and NAc mediates behavior of cocaine intake and motivational responses to psychostimulants through epigenetic regulation of BDNF in animals (Deng et al., 2010; Im et al., 2010). Recently, we have also shown that MeCP2 promotes behavioral responses to opioid reward through BDNF in rats (Zhang et al., 2014a). However, it is unclear how MeCP2 may function during opioid withdrawal. Our current results indicate that $\mathrm{MeCP} 2$ is downregulated during opioid withdrawal in emotion-regulating $\mathrm{CeA}$, consistent with an aversive state of negative emotion associated with opioid withdrawal.

Recently, increasing evidence suggests a pain-promoting role of MeCP2 in the mechanism of chronic pain development (Denk and McMahon, 2012). Clinically, patients with the Rett syndrome, a neurodevelopmental disorder caused by disruptive mutations in MeCP2, display decreased pain sensitivity (Downs et al., 2010). In animal studies, loss-of-function mutations in $\mathrm{MeCP} 2$ decrease pain recognition in mice; and MeCP2 expression and phosphorylation in rat spinal cord are altered under pain conditions (Géranton et al., 2007; Samaco et al., 2008; Tochiki et al., 2012). In a recent study, we have demonstrated a pain-promoting role of $\mathrm{MeCP} 2$ in central amygdala in an epigenetic mechanism for the development of chronic pain (Zhang et al., 2014a). However, it has yet to be demonstrated how pain affects MeCP2 expression and function in the context of repeated opioid exposure, which also increases $\mathrm{MeCP} 2$ expression (Zhang et al., 2014a). After opioid withdrawal with reduced $\mathrm{MeCP} 2$ activity in CeA, resultant changes in $\mathrm{MeCP} 2-$ regulated proteins, such as GluA1 of AMPARs, may play a dominant role in behaviors of opioid seeking and pain sensitivity. Thus, it appears that upregulated GluAl resulting from de-repression of Grial by MeCP2 in CeA may promote both opioid-seeking behavior and sensitization of pain behavior during opioid withdrawal. 
A

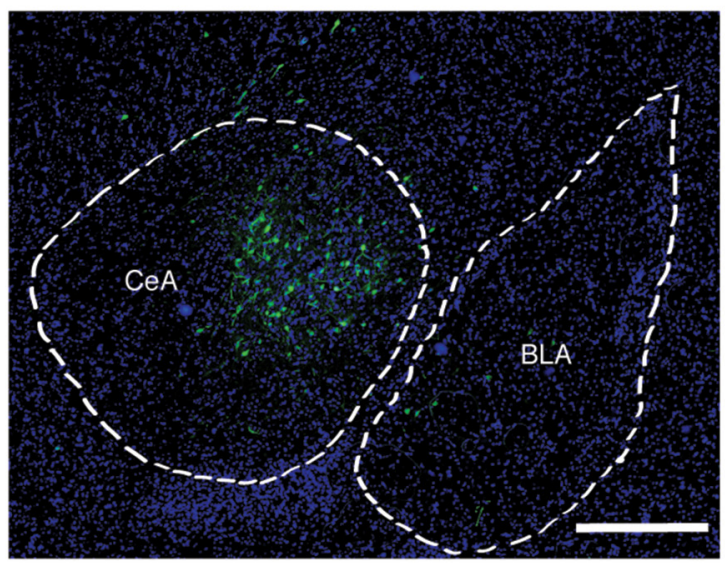

AAV-MeCP2

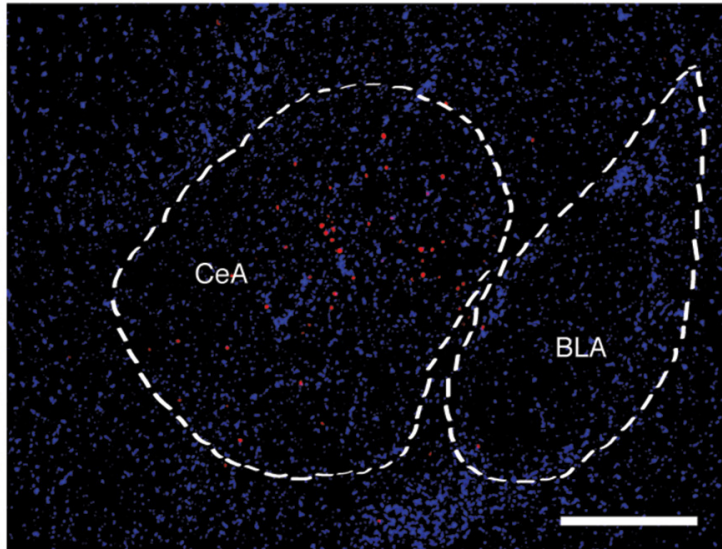

DAPI

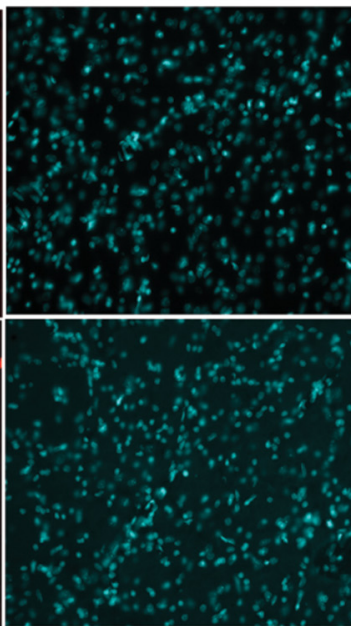

Merged

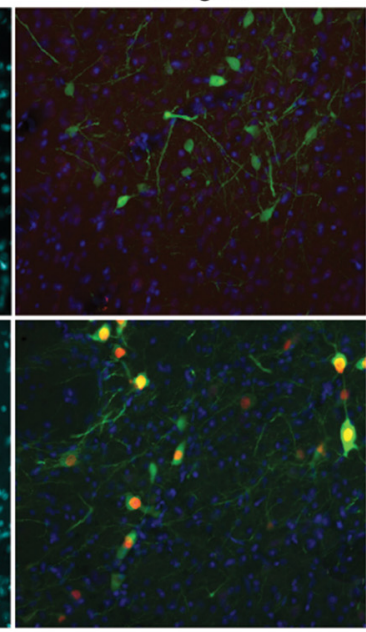

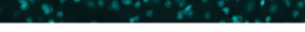

C
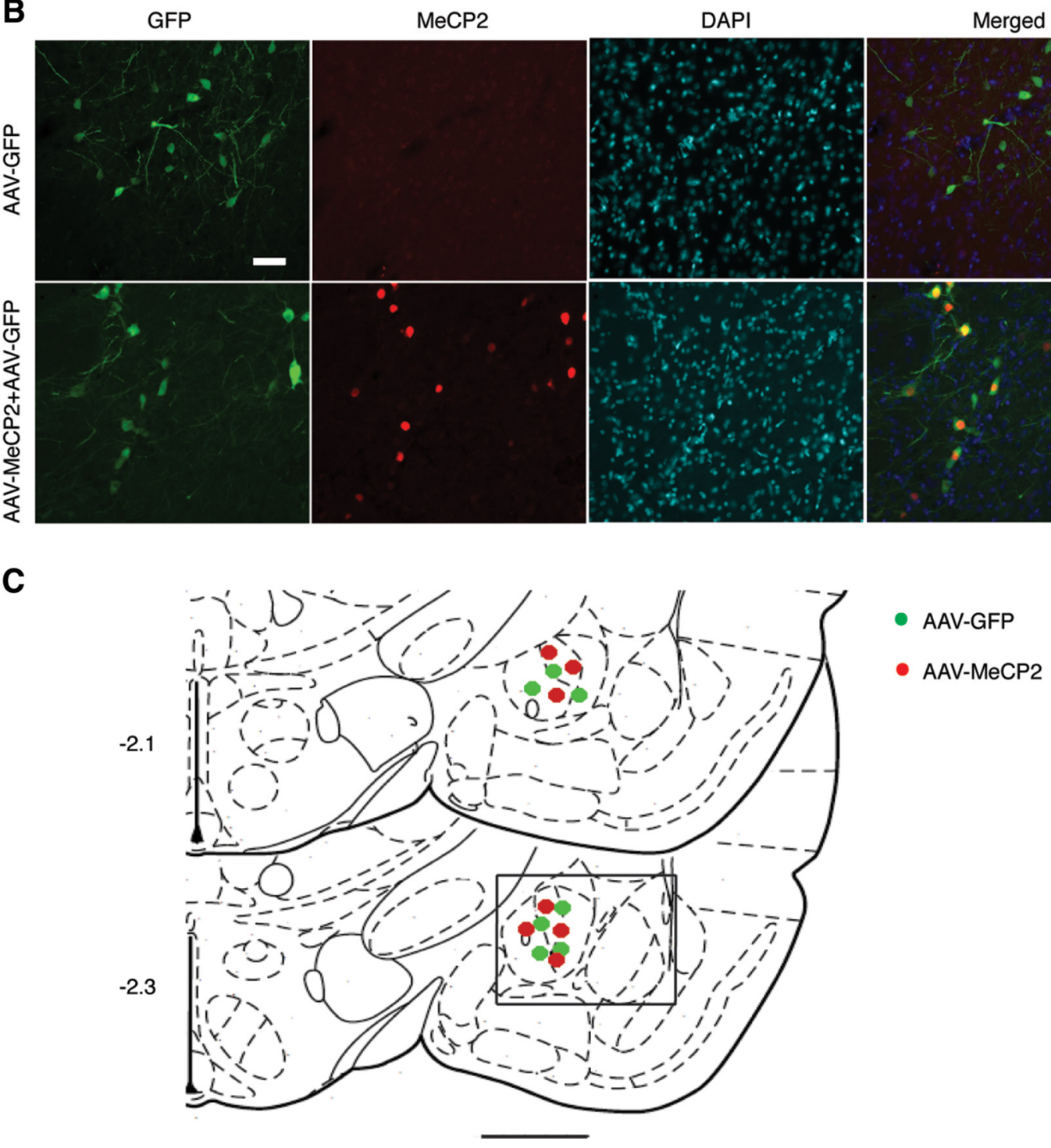

Figure 7. Immunohistochemical illustration of MeCP2 overexpression by viral vectors in CeA. $\boldsymbol{A}$, Representative images of expression of microinjected AAV-GFP vector (green), AAV-MeCP2 vector (red), and DAPI (blue) in CeA and BLA of naive rats. Scale bars, $400 \mu \mathrm{m} . \boldsymbol{B}$, Immunohistochemical images of expression of GFP, MeCP2, and DAPI in the CeA of a naive rat with CeA microinjection of AAV-GFP or the mix of AAV-MeCP2 and AAV-GFP. Scale bars, $50 \mu \mathrm{m}$. C, Schematic illustration of locations of cannula tips for CeA microinjection of control AAV-GFP vector (green dots) and MeCP2-overexpressing AAV-MeCP2 vector (red dots). The rectangular depicts the brain area shown in $\boldsymbol{A}$. Numbers on the left are distance (mm) from bregma. Scale bar, $1 \mathrm{~mm}$. 

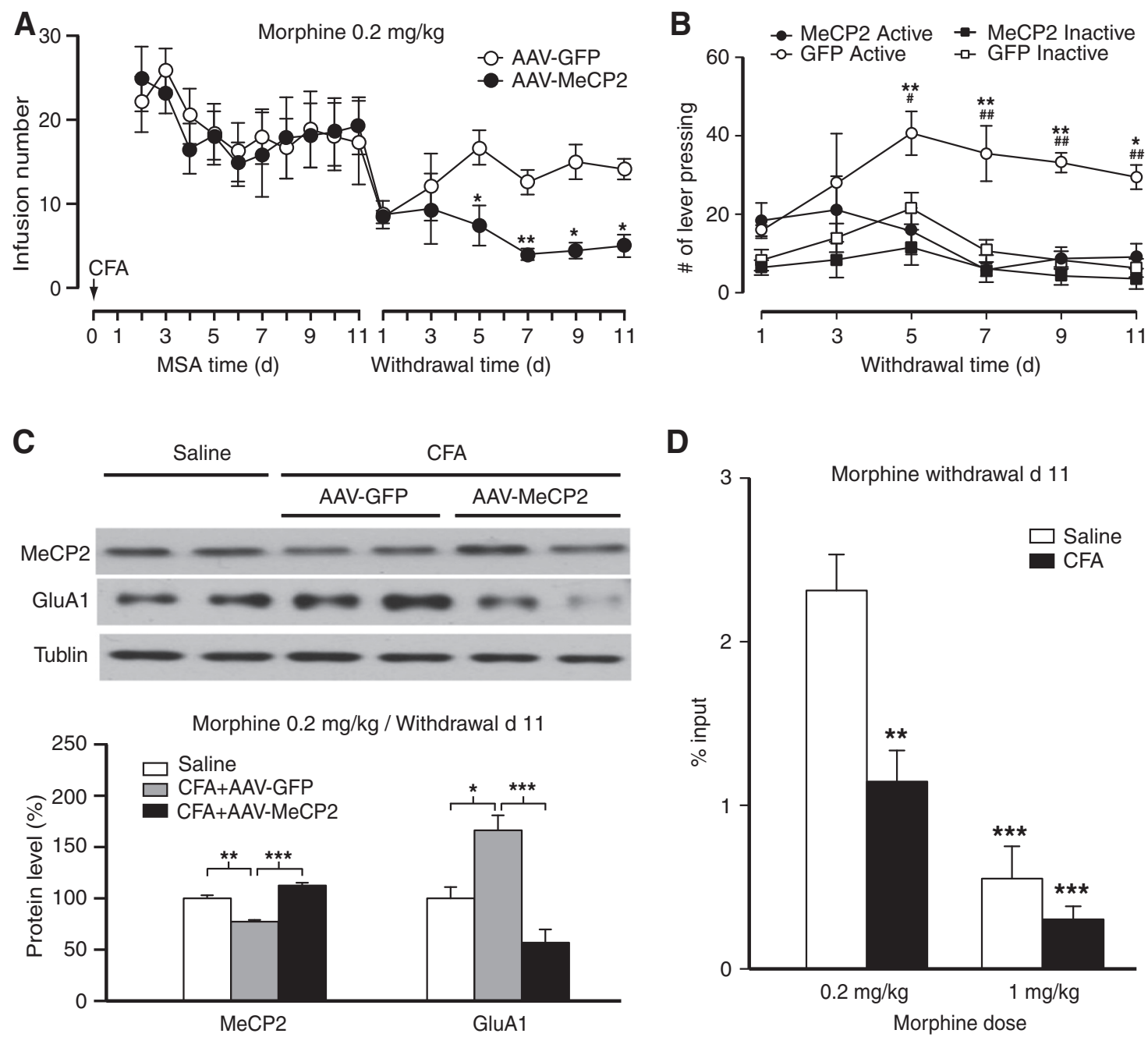

Figure 8. Viral overexpression of MeCP2 in CeA reverses the pain effects after morphine withdrawal. $A, B$, Infusion numbers $(A)$ and pressing of active and inactive levers ( $B$ ) in CFA-injected rats with CeA microinjection of AAV-GFP $(n=7)$ or AAV-MeCP2 $(n=7)$ before (MSA, $0.2 \mathrm{mg} / \mathrm{kg} /$ infusion) and after morphine withdrawal. C, Western blots data of MeCP2 and GluA1 proteins in the CeA of saline-injected $(n=4)$ and CFA-injected rats with CeA microinjection of AAV-GFP $(n=4)$ or AAV-MeCP2 $(n=4)$, and withdrawn from morphine $(0.2 \mathrm{mg} / \mathrm{kg} / \mathrm{infusion})$ on withdrawal day 11 . D, MeCP2 binding to the Gria1 promoter region in the CeA of rats injected with saline or CFA and withdrawn from low ( $n=4$ from 8 rats each group) or high dose morphine ( $n=3$ from 6 rats each group) on withdrawal day 11 (one-way and two-way ANOVA with Bonferroni post hoc test).

GluA1 subunits of AMPARs play a critical role in synaptic plasticity involved in brain function of learning and memory, and particularly in associative learning of drug reward (Bowers et al., 2010). Upregulated GluA1 alters the subunit composition of AMPARs and switches normally expressed GluA2-containing AMPARs to $\mathrm{Ca}^{2+}$-permeable, GluA2-lacking AMPARs with enhanced synaptic strength in glutamate neurotransmission (Isaac et al., 2007; Kauer and Malenka, 2007). Repeated treatments with morphine and cocaine increase GluA1 expression in the amygdala, NAc and the ventral tegmental area (VTA; Fitzgerald et al., 1996; Glass et al., 2005); and upregulation of GluA1 in VTA enhances the rewarding effect of morphine (Carlezon et al., 1997). We also have shown that GluAl overexpression in CeA promotes associative learning and acquisition of morphine reward (Cai et al., 2013). After withdrawal from cocaine selfadministration, the increased cocaine-seeking behavior (craving) is mediated by accumulation and increased synaptic function of GluA2-lacking, homomeric GluA1 AMPARs in NAc and VTA (Lu et al., 2003; Conrad et al., 2008; McCutcheon et al., 2011). The present study provides evidence for a similar promoting role of CeA GluA1 upregulation in morphine-seeking behavior after opioid withdrawal. This GluA1 role is in contrast to its role in promoting the acquisition and extinction of morphine reward measured by conditioned place preference in pain-free, nonopioid-dependent animals (Cai et al., 2013). It may reflect the interacting effects of pain and long-term opioid exposure on relative CeA levels of GluA1 and the behavioral outcomes of its upregulation.

Of particular interest is our finding that pain experience is able to maintain morphine-seeking behavior after withdrawal by upregulated GluA1 in CeA. Pain conditions have been shown to elevate the GluA1 level and associated AMPAR function in central pain-processing sites (Guan et al., 2003; Larsson and Broman, 2008; Xu et al., 2008). Thus, it is possible that pain initially increases CeA GluA1 level for facilitation of emotion-related learning and acquisition of pain, as well as opioid reward, and the GluA1 level then returns to a more sustainable level in the presence of sustained morphine exposure, as suggested by our recent studies (Cai et al., 2013; Zhang et al., 2014a). It remains unclear how the pain effect sustains to affect behavioral responses upon opioid withdrawal. One possibility is that pain causes sustained reduction in Grial methylation, resulting in decreased $\mathrm{MeCp} 2$ 
binding to Grial and Grial de-repression for GluA1 upregulation. This sustained pain effect may be the result of pain-induced, long-lasting maladaptations in the emotion-processing systems of affective pain including CeA (Price, 2000; Neugebauer et al., 2009).

Of note is our result that the pain maintenance of morphineseeking behavior is revealed in rats withdrawn from $0.2 \mathrm{mg} / \mathrm{kg}$ morphine, but not from $1 \mathrm{mg} / \mathrm{kg}$ morphine. Considering the clinical reports that $5 \mathrm{mg}$ morphine (i.v.) has significant reinforcing effect with abuse potential and a mid-dose of $\sim 15 \mathrm{mg}$ (i.v.) for recreational use in human subjects [weighing an average of 70 $\mathrm{kg}$, which is equal to $0.21 \mathrm{mg} / \mathrm{kg}(15 / 70=0.21)$; Comer et al., 2008; Stoops et al., 2010], the $1 \mathrm{mg} / \mathrm{kg}$ (i.v.) dose used in animals is strikingly five times higher by body weight. This near maximum morphine dose would cause near maximum behavioral responses upon withdrawal, which would prevent the revelation of further increase in response. Thus, a submaximal morphine dose is required to reveal the enhancing effect of pain during withdrawal.

In clinical pain management, misuse and abuse of prescription opioids has long been a healthcare concern and how pain affects the abuse liability of opioids remains unclear (Woolf and Hashmi, 2004; Ballantyne and LaForge, 2007; Højsted and Sjøgren, 2007). In previous animal studies, the operant behavior of opioid self-administration was used mostly as an alternative measurement of pain and did not yield a consensus effect of pain on opioid consumption (Colpaert et al., 2001; Martin and Ewan, 2008). In the rodent model of spinal nerve ligation, neuropathic pain is reported to attenuate the rewarding effect of opioids measured by rewarding brain stimulation or conditioned place preference (Ozaki et al., 2004; Ewan and Martin, 2011). Thus, the pain impact on established and steady behavior of opioid reward may depend on opioid doses, assessing methods of opioid reward and animal pain models. Although the present study does not show a significant change in the amount of self-administered morphine at the two doses under the pain condition, it reveals a long-lasting pain effect in maintaining morphine-seeking behavior after withdrawal. The prolonged presence of pain-induced aversion behavior of affective pain long after remission of sensory pain (Fig. 1) indicates that the pain-maintained morphineseeking behavior may reflect a behavioral craving for opioids to reduce the negative emotion of affective pain. In patients under opioid treatment for chronic pain, craving for opioid medication is highly correlated with the occurrence of opioid misuse (Wasan et al., 2009). Our results highlight the long-lasting pain effect on the risk of opioid misuse after opioid withdrawal and provide potential molecular targets for the treatment of opioid withdrawal-related aberrant behaviors.

In summary, the present study provides molecular and behavioral evidence supporting the notion that pain maintains opioidseeking behavior after abstinence through decreased MeCP2 repression of Grial expression and consequent GluA1 upregulation in CeA, an effect likely related to a prolonged state of aversive emotion associated with chronic pain. It also underscores the sustained effect of pain experience on the risk of aberrant behaviors of opioid misuse and abuse upon opioid withdrawal.

\section{References}

Baliki MN, Geha PY, Fields HL, Apkarian AV (2010) Predicting value of pain and analgesia: nucleus accumbens response to noxious stimuli changes in the presence of chronic pain. Neuron 66:149-160. CrossRef Medline

Ballantyne JC, LaForge KS (2007) Opioid dependence and addiction during opioid treatment of chronic pain. Pain 129:235-255. CrossRef Medline
Bie B, Wang Y, Cai YQ, Zhang Z, Hou YY, Pan ZZ (2012) Upregulation of nerve growth factor in central amygdala increases sensitivity to opioid reward. Neuropsychopharmacology 37:2780-2788. CrossRef Medline

Bowers MS, Chen BT, Bonci A (2010) AMPA receptor synaptic plasticity induced by psychostimulants: the past, present, and therapeutic future. Neuron 67:11-24. CrossRef Medline

Bushnell MC, Ceko M, Low LA (2013) Cognitive and emotional control of pain and its disruption in chronic pain. Nat Rev Neurosci 14:502-511. CrossRef Medline

Cai YQ, Wang W, Hou YY, Zhang Z, Xie J, Pan ZZ (2013) Central amygdala GluA1 facilitates associative learning of opioid reward. J Neurosci 33: 1577-1588. CrossRef Medline

Carlezon WA Jr, Boundy VA, Haile CN, Lane SB, Kalb RG, Neve RL, Nestler EJ (1997) Sensitization to morphine induced by viral-mediated gene transfer. Science 277:812-814. CrossRef Medline

Chahrour M, Jung SY, Shaw C, Zhou X, Wong ST, Qin J, Zoghbi HY (2008) $\mathrm{MeCP} 2$, a key contributor to neurological disease, activates and represses transcription. Science 320:1224-1229. CrossRef Medline

Choi KH, Edwards S, Graham DL, Larson EB, Whisler KN, Simmons D, Friedman AK, Walsh JJ, Rahman Z, Monteggia LM, Eisch AJ, Neve RL, Nestler EJ, Han MH, Self DW (2011) Reinforcement-related regulation of AMPA glutamate receptor subunits in the ventral tegmental area enhances motivation for cocaine. J Neurosci 31:7927-7937. CrossRef Medline

Colpaert FC, Tarayre JP, Alliaga M, Bruins Slot LA, Attal N, Koek W (2001) Opiate self-administration as a measure of chronic nociceptive pain in arthritic rats. Pain 91:33-45. CrossRef Medline

Comer SD, Sullivan MA, Whittington RA, Vosburg SK, Kowalczyk WJ (2008) Abuse liability of prescription opioids compared with heroin in morphine-maintained heroin abusers. Neuropsychopharmacology 33: 1179-1191. CrossRef Medline

Conrad KL, Tseng KY, Uejima JL, Reimers JM, Heng LJ, Shaham Y, Marinelli M, Wolf ME (2008) Formation of accumbens GluR2-lacking AMPA receptors mediates incubation of cocaine craving. Nature 454:118-121. CrossRef Medline

Deng JV, Rodriguiz RM, Hutchinson AN, Kim IH, Wetsel WC, West AE (2010) $\mathrm{MeCP} 2$ in the nucleus accumbens contributes to neural and behavioral responses to psychostimulants. Nat Neurosci 13:1128-1136. CrossRef Medline

Denisco RA, Chandler RK, Compton WM (2008) Addressing the intersecting problems of opioid misuse and chronic pain treatment. Exp Clin Psychopharmacol 16:417-428. CrossRef Medline

Denk F, McMahon SB (2012) Chronic pain: emerging evidence for the involvement of epigenetics. Neuron 73:435-444. CrossRef Medline

Downs J, Géranton SM, Bebbington A, Jacoby P, Bahi-Buisson N, Ravine D, Leonard H (2010) Linking MECP2 and pain sensitivity: the example of Rett syndrome. Am J Med Genet A 152A:1197-1205. CrossRef Medline

Ewan EE, Martin TJ (2011) Rewarding electrical brain stimulation in rats after peripheral nerve injury: decreased facilitation by commonly abused prescription opioids. Anesthesiology 115:1271-1280. CrossRef Medline

Fields H (2004) State-dependent opioid control of pain. Nat Rev Neurosci 5:565-575. CrossRef Medline

Fitzgerald LW, Ortiz J, Hamedani AG, Nestler EJ (1996) Drugs of abuse and stress increase the expression of GluR1 and NMDAR1 glutamate receptor subunits in the rat ventral tegmental area: common adaptations among cross-sensitizing agents. J Neurosci 16:274-282. Medline

Géranton SM, Morenilla-Palao C, Hunt SP (2007) A role for transcriptional repressor methyl-CpG-binding protein 2 and plasticity-related gene serum- and glucocorticoid-inducible kinase 1 in the induction of inflammatory pain states. J Neurosci 27:6163-6173. CrossRef Medline

Glass MJ, Kruzich PJ, Colago EE, Kreek MJ, Pickel VM (2005) Increased AMPA GluR1 receptor subunit labeling on the plasma membrane of dendrites in the basolateral amygdala of rats self-administering morphine. Synapse 58:1-12. CrossRef Medline

Grimm JW, Hope BT, Wise RA, Shaham Y (2001) Neuroadaptation: incubation of cocaine craving after withdrawal. Nature 412:141-142. CrossRef Medline

Guan Y, Guo W, Zou SP, Dubner R, Ren K (2003) Inflammation-induced upregulation of AMPA receptor subunit expression in brain stem pain modulatory circuitry. Pain 104:401-413. CrossRef Medline

Guy J, Cheval H, Selfridge J, Bird A (2011) The role of MeCP2 in the brain. Annu Rev Cell Dev Biol 27:631-652. CrossRef Medline 
Hayashi Y, Shi SH, Esteban JA, Piccini A, Poncer JC, Malinow R (2000) Driving AMPA receptors into synapses by LTP and CaMKII: requirement for GluR1 and PDZ domain interaction. Science 287:2262-2267. CrossRef Medline

Højsted J, Sjøgren P (2007) Addiction to opioids in chronic pain patients: a literature review. Eur J pain 11:490-518. CrossRef Medline

Hummel M, Lu P, Cummons TA, Whiteside GT (2008) The persistence of a long-term negative affective state following the induction of either acute or chronic pain. Pain 140:436-445. CrossRef Medline

Hunt SP, Urch CE (2013) Pain, opiates, and addiction. In: Textbook of pain (McMahon SB, Koltzenburg M, eds), pp 351-361. Philadelphia: Elsevier.

Im HI, Hollander JA, Bali P, Kenny PJ (2010) MeCP2 controls BDNF expression and cocaine intake through homeostatic interactions with microRNA-212. Nat Neurosci 13:1120-1127. CrossRef Medline

Isaac JT, Ashby MC, McBain CJ (2007) The role of the GluR2 subunit in AMPA receptor function and synaptic plasticity. Neuron 54:859-871. CrossRef Medline

Jayanthi S, McCoy MT, Chen B, Britt JP, Kourrich S, Yau HJ, Ladenheim B, Krasnova IN, Bonci A, Cadet JL (2014) Methamphetamine downregulates striatal glutamate receptors via diverse epigenetic mechanisms. Biol Psychiatry 76:47-56. CrossRef Medline

Johansen JP, Fields HL, Manning BH (2001) The affective component of pain in rodents: direct evidence for a contribution of the anterior cingulate cortex. Proc Natl Acad Sci U S A 98:8077-8082. CrossRef Medline

Jones PL, Veenstra GJ, Wade PA, Vermaak D, Kass SU, Landsberger N, Strouboulis J, Wolffe AP (1998) Methylated DNA and MeCP2 recruit histone deacetylase to repress transcription. Nat Genet 19:187-191. CrossRef Medline

Kauer JA, Malenka RC (2007) Synaptic plasticity and addiction. Nat Rev Neurosci 8:844-858. CrossRef Medline

Larsson M, Broman J (2008) Translocation of GluR1-containing AMPA receptors to a spinal nociceptive synapse during acute noxious stimulation. J Neurosci 28:7084-7090. CrossRef Medline

Leknes S, Tracey I (2008) A common neurobiology for pain and pleasure. Nat Rev Neurosci 9:314-320. CrossRef Medline

Li YQ, Li FQ, Wang XY, Wu P, Zhao M, Xu CM, Shaham Y, Lu L (2008) Central amygdala extracellular signal-regulated kinase signaling pathway is critical to incubation of opiate craving. J Neurosci 28:13248-13257. CrossRef Medline

Lu L, Grimm JW, Shaham Y, Hope BT (2003) Molecular neuroadaptations in the accumbens and ventral tegmental area during the first 90 days of forced abstinence from cocaine self-administration in rats. J Neurochem 85:1604-1613. CrossRef Medline

Lu L, Hope BT, Dempsey J, Liu SY, Bossert JM, Shaham Y (2005) Central amygdala ERK signaling pathway is critical to incubation of cocaine craving. Nat Neurosci 8:212-219. CrossRef Medline

Mahanty NK, Sah P (1998) Calcium-permeable AMPA receptors mediate long-term potentiation in interneurons in the amygdala. Nature 394:683687. CrossRef Medline

Markou A, Weiss F, Gold LH, Caine SB, Schulteis G, Koob GF (1993) Animal models of drug craving. Psychopharmacology 112:163-182. CrossRef Medline

Martin TJ, Ewan E (2008) Chronic pain alters drug self-administration: implications for addiction and pain mechanisms. Exp clin Psychopharmacol 16:357-366. CrossRef Medline

McCutcheon JE, Wang X, Tseng KY, Wolf ME, Marinelli M (2011) Calcium-permeable AMPA receptors are present in nucleus accumbens synapses after prolonged withdrawal from cocaine self-administration but not experimenter-administered cocaine. J Neurosci 31:5737-5743. CrossRef Medline

Minozzi S, Amato L, Davoli M (2013) Development of dependence following treatment with opioid analgesics for pain relief: a systematic review. Addiction 108:688-698. CrossRef Medline

Nan X, Ng HH, Johnson CA, Laherty CD, Turner BM, Eisenman RN, Bird A (1998) Transcriptional repression by the methyl-CpG-binding protein MeCP2 involves a histone deacetylase complex. Nature 393:386-389. CrossRef Medline

Neugebauer V, Galhardo V, Maione S, Mackey SC (2009) Forebrain pain mechanisms. Brain Res Rev 60:226-242. CrossRef Medline
Norwood CS, Cornish JL, Mallet PE, McGregor IS (2003) Pre-exposure to the cannabinoid receptor agonist CP 55940 enhances morphine behavioral sensitization and alters morphine self-administration in Lewis rats. Eur J Pharmacol 465:105-114. CrossRef Medline

Ozaki S, Narita M, Ozaki M, Khotib J, Suzuki T (2004) Role of extracellular signal-regulated kinase in the ventral tegmental area in the suppression of the morphine-induced rewarding effect in mice with sciatic nerve ligation. J Neurochem 88:1389-1397. CrossRef Medline

Passik SD, Kirsh KL (2011) Addictions in pain clinics and pain treatment. Ann N Y Acad Sci 1216:138-143. CrossRef Medline

Price DD (2000) Psychological and neural mechanisms of the affective dimension of pain. Science 288:1769-1772. CrossRef Medline

Rumpel S, LeDoux J, Zador A, Malinow R (2005) Postsynaptic receptor trafficking underlying a form of associative learning. Science 308:83-88. CrossRef Medline

Samaco RC, Fryer JD, Ren J, Fyffe S, Chao HT, Sun Y, Greer JJ, Zoghbi HY, Neul JL (2008) A partial loss of function allele of methyl-CpG-binding protein 2 predicts a human neurodevelopmental syndrome. Hum Mol Genet 17:1718-1727. CrossRef Medline

Sánchez-Cardoso P, Higuera-Matas A, Martín S, Miguéns M, Del Olmo N, García-Lecumberri C, Ambrosio E (2009) Strain differences between Lewis and Fischer 344 rats in the modulation of dopaminergic receptors after morphine self-administration and during extinction. Neuropharmacology 57:8-17. CrossRef Medline

Stoops WW, Hatton KW, Lofwall MR, Nuzzo PA, Walsh SL (2010) Intravenous oxycodone, hydrocodone, and morphine in recreational opioid users: abuse potential and relative potencies. Psychopharmacology 212: 193-203. CrossRef Medline

Theberge FR, Pickens CL, Goldart E, Fanous S, Hope BT, Liu QR, Shaham Y (2012) Association of time-dependent changes in mu opioid receptor mRNA, but not BDNF, TrkB, or MeCP2 mRNA and protein expression in the rat nucleus accumbens with incubation of heroin craving. Psychopharmacology 224:559-571. CrossRef Medline

Tochiki KK, Cunningham J, Hunt SP, Géranton SM (2012) The expression of spinal methyl-CpG-binding protein 2, DNA methyltransferases and histone deacetylases is modulated in persistent pain states. Mol Pain 8:14. CrossRef Medline

Vargas-Perez H, Ting-A KR, Walton CH, Hansen DM, Razavi R, Clarke L, Bufalino MR, Allison DW, Steffensen SC, van der Kooy D (2009) Ventral tegmental area BDNF induces an opiate-dependent-like reward state in naive rats. Science 324:1732-1734. CrossRef Medline

Wasan AD, Butler SF, Budman SH, Fernandez K, Weiss RD, Greenfield SF, Jamison RN (2009) Does report of craving opioid medication predict aberrant drug behavior among chronic pain patients? Clin J Pain 25:193198. CrossRef Medline

Wenthold RJ, Petralia RS, Blahos J II, Niedzielski AS (1996) Evidence for multiple AMPA receptor complexes in hippocampal CA1/CA2 neurons. J Neurosci 16:1982-1989. Medline

Woolf CJ, Hashmi M (2004) Use and abuse of opioid analgesics: potential methods to prevent and deter non-medical consumption of prescription opioids. Curr Opin Investig Drugs 5:61-66. Medline

Xu H, Wu LJ, Wang H, Zhang X, Vadakkan KI, Kim SS, Steenland HW, Zhuo M (2008) Presynaptic and postsynaptic amplifications of neuropathic pain in the anterior cingulate cortex. J Neurosci 28:7445-7453. CrossRef Medline

Yasui DH, Xu H, Dunaway KW, Lasalle JM, Jin LW, Maezawa I (2013) $\mathrm{MeCP} 2$ modulates gene expression pathways in astrocytes. Mol Autism 4:3. CrossRef Medline

Zhang Z, Cai YQ, Zou F, Bie B, Pan ZZ (2011) Epigenetic suppression of GAD65 expression mediates persistent pain. Nat Med 17:1448-1455. CrossRef Medline

Zhang Z, Tao W, Hou YY, Wang W, Kenny PJ, Pan ZZ (2014a) MeCP2 repression of G9a in regulation of pain and morphine reward. J Neurosci 34:9076-9087. CrossRef Medline

Zhang Z, Tao W, Hou YY, Wang W, Lu YG, Pan ZZ (2014b) Persistent pain facilitates response to morphine reward by Downregulation of central amygdala GABAergic function. Neuropsychopharmacology 39:22632271. CrossRef Medline 